\title{
Tory doświadczalne i ich rola w badaniach taboru oraz infrastruktury kolejowej
}

\author{
Andrzej MASSEL ${ }^{1}$
}

\begin{abstract}
Streszczenie
W celu przyspieszenia procesu wdrażania innowacyjnych rozwiązań w transporcie kolejowym, przy jednoczesnym zapewnieniu wymaganej ich jakości, w niektórych krajach Europy i Świata wykorzystuje się poligony badawcze. W szczególności, do takich poligonów należą tory doświadczalne, a ich szczególną grupę stanowią okręgi doświadczalne. Zaletą wykorzystywania w badaniach specjalistycznej infrastruktury jest przede wszystkim możliwość uzyskania warunków analogicznych do panujących na liniach kolejowych bez wzajemnego wpływu badań na realizację zadań przewozowych, zapewnienia takich samych warunków dla badań porównawczych oraz zagwarantowania warunków do prowadzenia badań w sposób ciągły, co wydatnie skraca czas ich trwania i przyspiesza uzyskanie wyników. W artykule przedstawiono parametry eksploatowanych torów doświadczalnych, dokonano także ich porównania i klasyfikacji w kontekście możliwości prowadzenia różnego rodzaju badań.
\end{abstract}

Słowa kluczowe: tor doświadczalny, okrąg doświadczalny, badania, tabor kolejowy, infrastruktura

\section{Wprowadzenie}

Rozwój techniki kolejowej trwa nieprzerwanie od prawie 200 lat i w dużej mierze jest wynikiem sukcesywnie wprowadzanych innowacji. Dotyczą one zarówno infrastruktury obejmującej konstrukcję drogi kolejowej, systemy sterowania oraz zasilania, jak i poruszających się po tej infrastrukturze pojazdów. Proces wprowadzania nowych rozwiązań technicznych jest wieloetapowy i z natury jest rozłożony w czasie. Obejmuje on etap poszukiwań nowych perspektywicznych rozwiązań, etap projektowania, etap badań laboratoryjnych oraz etap badań w warunkach eksploatacyjnych. Te wszystkie etapy są ważne ze względu na potrzebę zapewnienia bezpieczeństwa eksploatacji, a także w celu uniknięcia usterek („,chorób wieku dziecięcego"), zwłaszcza w jej początkowym okresie.

W celu przyspieszenia procesu wdrażania innowacyjnych rozwiązań $\mathrm{w}$ transporcie kolejowym, przy zapewnieniu wymaganej ich jakości, w niektórych krajach Europy i Świata wykorzystuje się poligony badawcze. W szczególności należą do nich tory doświadczalne, a jedną $\mathrm{z}$ ich grup stanowią okręgi doświadczalne. Zaletami wykorzystywania $\mathrm{w}$ badaniach takiej specjalistycznej infrastruktury są przede wszystkim: możliwość uzyskania warunków analogicznych do panujących na liniach kolejowych bez negatywnego wpływu badań na realizację zadań przewozowych, zapewnienie takich samych warunków do badań porównawczych, zagwarantowanie prowadzenia badań w sposób ciągły, skrócenie czasu ich trwania i przyspieszenie uzyskania wyników. Tak więc, tory doświadczalne są poligonami badawczymi umożliwiającymi prowadzenie kompleksowych badań taboru oraz infrastruktury w różnych dziedzinach kolejnictwa. Celem niniejszego artykułu jest przedstawienie parametrów eksploatowanych torów doświadczalnych, ich porównanie i klasyfikacja, w kontekście możliwości prowadzenia różnego rodzaju badań. W szerszym zakresie tę tematykę podjęto w wydanej w 2021 roku monografii [12].

\section{Jazdy $z$ dużymi prędkościami na eksploatowanych liniach kolejowych}

W tym rozdziale scharakteryzowano wybrane doświadczenia kolei zagranicznych w zakresie przeprowadzania badań taboru przy dużych prędkościach jazdy. Niektóre z tych doświadczeń sięgają jeszcze początków XX wieku, inne zaś dotyczą już wieku XXI. Przez wiele lat praktycznie jedyną możliwością doświadczalnego sprawdzenia pojazdów szynowych, a także elementów infrastruktury kolejowej przy du-

${ }^{1}$ Dr inż.; Instytut Kolejnictwa, Zastępca Dyrektora ds. Studiów i Projektów Badawczych; amassel@ikolej.pl. 
żych prędkościach jazdy, umożliwiały jazdy wykonywane na eksploatowanych odcinkach linii kolejowych. Zasadniczym warunkiem przeprowadzenia takich przejazdów była dogodna charakterystyka układu geometrycznego toru (odpowiednio duże promienie łuków, wartości przechyłek i długości krzywych przejściowych).

Na początku XX wieku przeprowadzono w Niemczech badania elektrycznych pojazdów trakcyjnych zasilanych prądem trójfazowym. Do badań wykorzystano linię Królewsko-Pruskiej Kolei Wojskowej (Königlich Preußische Militär-Eisenbahn) o długości 45,6 km, którą zbudowano w 1875 roku. Kolej łączyła stację Berlin-Schöneberg z Kummerdorf przez Marienfelde i Zossen. Z jednej strony linia służyła jako poligon szkoleniowy dla jednostek kolejowych, z drugiej zaś zapewniała dojazd do poligonów zlokalizowanych na południe od Berlina. Od listopada 1888 roku linia została udostępniona dla regularnego ruchu pasażerskiego. Nie był on jednak zbyt intensywny - na przełomie wieków trasą kursowało kilka par pociągów osobowych dziennie. Od 1901 roku na odcinku Marienfelde - Zossen odbywały się badania lokomotyw i wagonów elektrycznych, a także jazdy z bardzo dużymi prędkościami. W tym celu odcinek o długości $23 \mathrm{~km}$ zelektryfikowano prądem trójfazowym o napięciu $10 \mathrm{kV}$ i częstotliwości $50 \mathrm{~Hz}$. Sieć trakcyjną z trzema przewodami jezdnymi zawieszono $\mathrm{z}$ boku toru na wysokości od 5,5 m do 7,5 m. Już w 1901 roku, podczas jazd doświadczalnych, była przekraczana prędkość $160 \mathrm{~km} / \mathrm{h}$. W czasie od września do końca listopada 1903 roku, po wzmocnieniu nawierzchni (w szczególności po zabudowaniu szyn cięższego typu), zrealizowano jazdy wagonów elektrycznych firm Siemens oraz AEG z prędkościami powyżej $200 \mathrm{~km} / \mathrm{h}$, a 28 października 1903 roku wagon elektryczny konstrukcji AEG osiągnął prędkość $210,2 \mathrm{~km} / \mathrm{h}$.

Okresem ważnym dla rozwoju kolei były lata trzydzieste XX wieku, kiedy podjęto działania na rzecz zwiększenia prędkości pociąó́w. Zasadniczym celem tych działań była poprawa konkurencyjności kolei w stosunku do innych środków transportu, zwłaszcza samochodu i samolotu. W drugiej połowie lat trzydziestych, największe prędkości wybranych pociągów osiągane w codziennej eksploatacji wynosiły $140-160 \mathrm{~km} / \mathrm{h}$. Dotyczyło to przede wszystkim takich krajów jak Niemcy, Stany Zjednoczone, Wielka Brytania, Francja i Włochy. Ale już wtedy wiodące koleje i producenci taboru szynowego pracowali nad rozwiązaniami umożliwiającymi osiąganie w praktyce jeszcze większych prędkości.

Przykładowo, 11 maja 1936 roku niemiecki parowóz pospieszny serii 05 , wyprodukowany przez zakłady Borsiga, prowadził skład pociągu o masie 197 ton (skład był złożony z 3 wagonów pasażerskich oraz 1 wagonu pomiarowego), osiągając na linii Ber- lin - Hamburg prędkość maksymalną 200,4 km/h. Jazda $\mathrm{z}$ największą prędkością miała miejsce na szlaku Friesack - Vietznitz na odcinku pomiędzy stacjami węzłowymi Neustadt i Nauen. Należy zwrócić uwagę, że linia Berlin - Hamburg była w tamtym okresie najlepiej przygotowana do jazd $\mathrm{z}$ dużymi prędkościami. Charakteryzuje się ona szczególnie łagodnym ukształtowaniem $\mathrm{w}$ płaszczyźnie poziomej i pionowej. Od 1933 roku na tej trasie regularnie kursowały spalinowe pociągi ekspresowe o prędkości maksymalnej $160 \mathrm{~km} / \mathrm{h}$. W związku z ruchem szybkich pociągów, droga hamowania wyznaczona przez odległość między tarczą ostrzegawczą i semaforem, została wydłużona do $1200 \mathrm{~m}$.

W dniu 3 lipca 1938 roku, parowóz kolei LNER (London North Eastern Railway) serii A4 o nazwie Mallard (rys. 1), osiągnął na East Coast Main Line (linii magistralnej łączącej Londyn z Edynburgiem) prędkość maksymalną $126 \mathrm{mil} \mathrm{na} \mathrm{godzinę}(203 \mathrm{~km} / \mathrm{h})$. Podobnie jak w przypadku linii Berlin - Hamburg, również na linii LNER kursowały szybkie planowe pociągi pasażerskie. Były one prowadzone trakcją parową, a ich maksymalna prędkość wynosiła 90 mil na godzinę $(145 \mathrm{~km} / \mathrm{h})$. Miejsce rekordowej jazdy znajdowało się na odcinku Grantham - Peterborough.

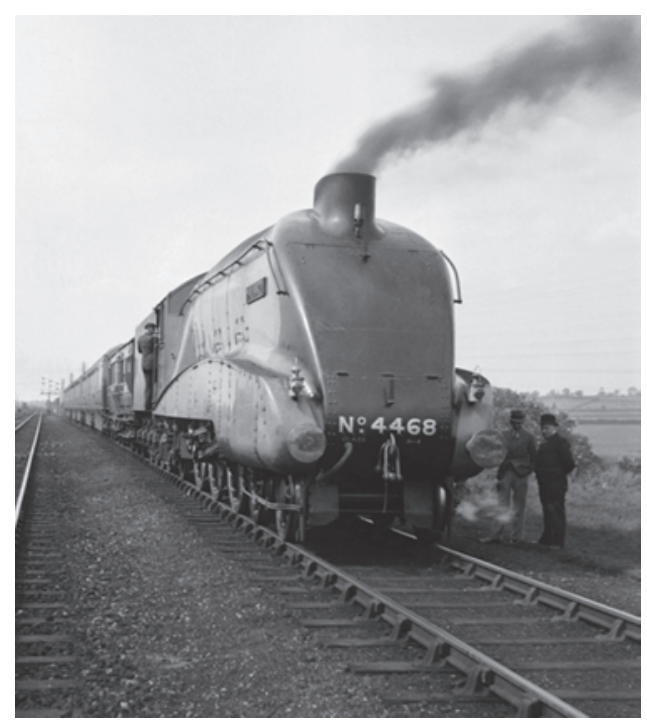

Rys. 1. Parowóz A4 przed rekordową jazdą [źródło: www. yorkpress.co.uk]

Również po II wojnie światowej, po zakończeniu odbudowy kolei, na nowo podjęto badania dotyczące możliwości zwiększenia prędkości pociągów. Najbardziej spektakularne jazdy pociągów z bardzo dużymi prędkościami na konwencjonalnej infrastrukturze kolejowej miały miejsce wiosną 1955 roku we Francji. Odbyły się one na linii Bordeaux - Dax, a do prób wybrano jej odcinek o długości $66 \mathrm{~km}$ pomiędzy stacjami Facture i Morcenx, odznaczający się bardzo dogodnym układem geometrycznym. Na odcin- 
ku prób były zlokalizowane stacje (z rozjazdami krzyżowymi), a także skrzyżowania $\mathrm{w}$ poziomie $\mathrm{z}$ drogami kołowymi. Odcinek ten był (i jest nadal) zasilany napięciem 1,5 kV prądu stałego. Podczas testów dokonano dwóch rekordowych przejazdów. Pierwszy miał miejsce w dniu 28 marca 1955 roku z lokomotywą elektryczną CC 7107, która osiągnęła prędkość $320 \mathrm{~km} / \mathrm{h}$. Następnego dnia, 29 marca 1955 roku, powtórzono próbę, jednak z inną lokomotywą BB 9004 (rys. 2). Osiągnięto wówczas prędkość $331 \mathrm{~km} / \mathrm{h}$.

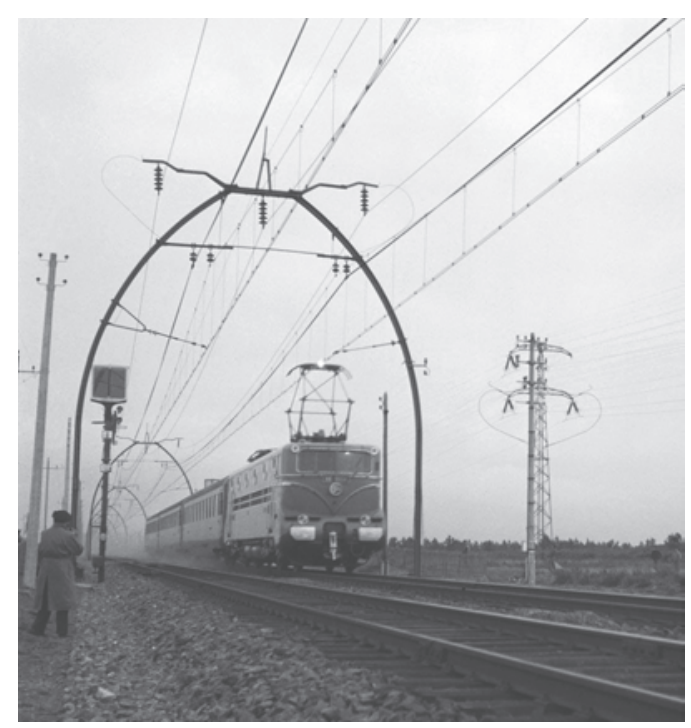

Rys. 2. Przejazd pociągu testowego prowadzonego lokomotywą BB 9004 w dniu 29 marca 1955 r. [źródło: SNCF]

$\mathrm{O}$ tym, jak z wielkim ryzykiem wiązały się $\mathrm{w}$ tamtych czasach jazdy z prędkościami przekraczającymi $300 \mathrm{~km} / \mathrm{h}$ świadczy fakt, że zakończyły się one poważnymi deformacjami toru i zniszczeniem (spaleniem) sieci trakcyjnej. Warto przy tym zwrócić uwagę, że jazdy z 1955 r. odbywały się z prędkościami poważnie odbiegającymi od wartości stosowanych na kolejach francu- skich w normalnej eksploatacji (do $140 \mathrm{~km} / \mathrm{h}$ ). Dopiero w 1957 r. dla prestiżowego pociągu „Mistral” z Paryża do Nicei wyjątkowo dopuszczono prędkość $150 \mathrm{~km} / \mathrm{h}$ $[10,11]$. Tymczasem prędkości osiągnięte $\mathrm{w}$ jazdach próbnych były ponad dwukrotnie większe (tabl. 1).

Jazdy na eksploatowanych liniach kolejowych, z prędkościami znacznie przekraczającymi wartości osiągane w normalnych warunkach ruchowych, były prowadzone także $\mathrm{w}$ latach późniejszych $\mathrm{w}$ bardzo wielu krajach. Interesujący może być przykład badań przeprowadzonych w 1985 roku na kolejach niemieckich na odcinku Bielefeld - Hamm, między stacjami Rheda-Wiedenbrück i Oelde. W listopadzie 1985 r. prototypowy pociąg ICE/V (InterCityExperimental) osiągnął na tym odcinku prędkość $317 \mathrm{~km} / \mathrm{h}$, a więc znacząco więcej niż prędkość eksploatacyjna wynosząca $200 \mathrm{~km} / \mathrm{h}$. Wszystkie jazdy pociągu ICE/V odbywały się $\mathrm{z}$ zachowaniem specjalnych warunków bezpieczeństwa. Sąsiedni tor był zamykany na czas prób, po każdej jeździe zaś stan toru był sprawdzany wagonem pomiarowym.

W Rosji, największą jak dotąd prędkość pociągu $281 \mathrm{~km} / \mathrm{h}$ osiągnięto w dniu 2 maja 2009 roku podczas przejazdu elektrycznego zespołu trakcyjnego dużych prędkości Sapsan (produkcji Siemens) na linii Sankt Petersburg - Moskwa, na szlaku Okułowka Mstinski Most. Na tej linii, pociągi pasażerskie kursowały dotychczas z prędkością $200 \mathrm{~km} / \mathrm{h}$.

W Polsce, jazdy z bardzo dużymi prędkościami były przeprowadzane na Centralnej Magistrali Kolejowej (CMK). W maju 1994 roku na odcinku w rejonie posterunku Biała Rawska elektryczny zespół trakcyjny kolei włoskich FS ETR460 Pendolino osiągnął prędkość $250 \mathrm{~km} / \mathrm{h}$, natomiast w listopadzie 2013 roku na szlaku Psary - Góra Włodowska były przeprowadzone jazdy elektrycznego zespołu trakcyjnego ED250 dla PKP Intercity, podczas których osiągnięto prędkość $293 \mathrm{~km} / \mathrm{h}$. W następnych latach,

Wybrane jazdy z bardzo dużymi prędkościami na eksploatowanych liniach kolejowych

\begin{tabular}{|l|l|c|c|c|}
\hline \multicolumn{1}{|c|}{ Data } & \multicolumn{1}{|c|}{ Odcinek } & $\begin{array}{c}\text { Prędkość eksploatacyjna } \\
\boldsymbol{V}_{\max (\boldsymbol{e})}[\mathbf{k m} / \mathbf{h}]\end{array}$ & $\begin{array}{c}\text { Prędkość jazdy testowej } \\
\boldsymbol{V}_{\max (t)}[\mathbf{k m} / \mathbf{h}]\end{array}$ & $\boldsymbol{V}_{\max (t)} / V_{\max (\boldsymbol{e})}$ \\
\hline $\mathbf{1 1 . 0 5 . 1 9 3 6}$ & Neustadt - Nauen & 160 & 200 & 1,25 \\
\hline $\mathbf{0 3 . 0 7 . 1 9 3 8}$ & Grantham - Peterborough & 145 & 203 & 1,40 \\
\hline $\mathbf{2 9 . 0 3 . 1 9 5 5}$ & Facture - Morcenx & 140 & 331 & 2,36 \\
\hline $\mathbf{2 6 . 1 1 . 1 9 8 5}$ & Rheda-Wiedenbrück - Oelde & 200 & 317 & 1,59 \\
\hline $\mathbf{0 2 . 0 5 . 2 0 0 9}$ & Okułowka - Mstinski Most & 200 & 281 & 1,41 \\
\hline $\mathbf{2 4 . 1 1 . 2 0 1 3}$ & Góra Włodowska - Psary & 160 & 293 & 1,83 \\
\hline
\end{tabular}

[Źródło: opracowanie własne].

\footnotetext{
${ }^{2}$ Prędkość eksploatacyjna na danym odcinku w trakcie jazdy testowej.
} 
na CMK kilkakrotnie wykonywano przejazdy zespołem ED250 z prędkością $275 \mathrm{~km} / \mathrm{h}$. Prowadzono je podczas badań rozjazdów nowych konstrukcji (produkowanych przez różnych producentów), zabudowanych między innymi na stacjach Strzałki oraz Psary.

\section{Wykorzystanie do jazd testowych nowej infrastruktury kolejowej przed przekazaniem jej do eksploatacji}

W celu przeprowadzenia badań infrastruktury kolejowej oraz pojazdów szynowych, zwłaszcza przeznaczonych do dużych prędkości, wykorzystuje się niekiedy odcinki linii kolejowych przed ich formalnym przekazaniem do eksploatacji. Umożliwia to wykonanie badań na infrastrukturze wysokiej jakości bez ingerowania w normalny ruch kolejowy. Najbardziej spektakularnymi przykładami takich testów były:

- jazdy pociągu TGV przeprowadzone $\mathrm{w}$ lutym 1981 roku na pierwszym odcinku linii Południowo-Wschodniej (LGV Sud-Est), podczas których osiągnięto prędkość $380 \mathrm{~km} / \mathrm{h}$ (oficjalne otwarcie linii nastąpiło we wrześniu 1981 roku);

- jazdy pociągu ICE/V na odcinku linii Hannover Würzburg w maju 1988 roku z osiągnięciem prędkości 406,9 km/h (przed częściowym otwarciem linii w dniu 29 maja 1988 roku);

- jazdy pociągu TGV na odcinku linii Atlantyckiej (LGV Atlantique - odgałęzienie w kierunku Tours) w dniu 5 grudnia 1989 roku, zakończone osiągnięciem prędkości $482,4 \mathrm{~km} / \mathrm{h} \mathrm{i} \mathrm{w}$ dniu 18 maja 1990 roku z prędkością 515,3 km/h, przed oddaniem linii do eksploatacji (25 września 1990 roku);

- jazdy pociągu TGV na linii Wschodnio-Europejskiej (LGV Est européenne) w dniu 3 kwietnia 2007 roku z osiągnięciem prędkości 574,8 km/h (otwarcie linii do normalnego ruchu nastąpiło 10 czerwca 2007 roku), rysunek 3.

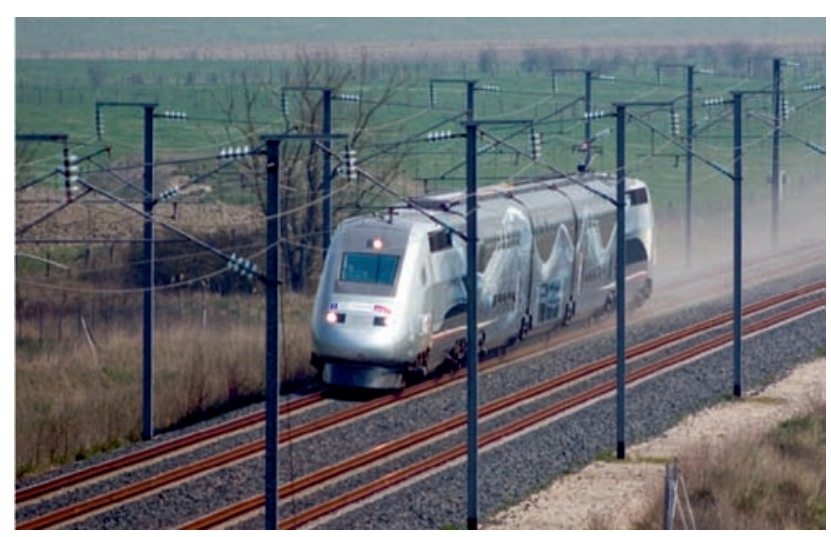

Rys. 3. Przejazd pociągu TGV z prędkością 574,8 km/h w 2007 r. [źródło: $\mathrm{SNCF}$ ]

\section{Charakterystyka istniejących torów doświadczalnych na świecie}

Konieczność zapewnienia bezpieczeństwa podczas prowadzenia badań taboru szynowego, a także badań infrastruktury i jej współdziałania z pojazdami, spowodowała że na potrzeby takich badań zbudowano poligony badawcze. W niniejszym rozdziale przedstawiono charakterystykę eksploatowanych torów doświadczalnych.

\subsection{Poligony badawcze WNIIŻT (Rosja)}

Wszechrosyjski Instytut Naukowo-Badawczy Transportu Kolejowego Spółka Akcyjna (AO WNIIŻT) dysponuje dwoma poligonami badawczymi: okręgiem doświadczalnym w Szczerbince oraz odcinkiem doświadczalnym Biełorieczenskaja-Majkop, zlokalizowanym na Kolei Północno-Kaukaskiej.

Pierwszą koncepcję prowadzenia badań taboru kolejowego na specjalnym torze badawczym przedstawił w 1901 roku prof. Jurij W. Łomonosow z Instytutu Inżynierów Komunikacji w Petersburgu - wybitny specjalista z zakresu badań charakterystyk trakcyjnych lokomotyw. W 1912 roku, profesor Łomonosow zaproponował utworzenie specjalnej jednostki organizacyjnej, której zadaniem byłoby przeprowadzanie doświadczeń $\mathrm{z}$ parowozami. $\mathrm{W}$ praktyce tę ideę zrealizowano znacznie później, po zbudowaniu pierwszego na świecie okręgu doświadczalnego. Okrąg ten powstał w 1932 roku przy stacji Szczerbinka (nazywającej się wtedy Butowo) pod Moskwą, położonej na $34 \mathrm{~km} \mathrm{li-}$ nii kolejowej Moskwa - Kursk. Celem jego budowy było zapewnienie możliwości wykonywania zestandaryzowanych i porównawczych badań taboru oraz infrastruktury $\mathrm{w}$ warunkach możliwie zbliżonych do rzeczywistych. W tamtym czasie, do prowadzenia badań służył jeden tor w kształcie zamkniętej pętli o promieniu $956 \mathrm{~m}$. Powstało również odpowiednie zaplecze techniczne, w tym lokomotywownia, wagonownia, podstacja trakcyjna, warsztaty oraz laboratorium. Opracowaniem koncepcji toru, jego projektowaniem i budową kierował profesor N. Biełokoń [8].

Wybudowanie okręgu doświadczalnego w pierwszej kolejności umożliwiło podjęcie badań charakterystyk lokomotyw dla różnych trybów ich pracy. $\mathrm{Na}$ okręgu w Szczerbince bardzo szybko rozpoczęto badania różnych typów pojazdów szynowych. Pierwszym obiektem takich badań był parowóz serii $\mathrm{E}$ (Э $\left.{ }^{\mathrm{MO}} 710-53\right)$ [7], następnie w 1933 roku, przeprowadzono badania pierwszej lokomotywy spalinowej (se-

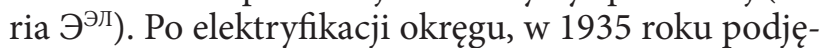
to badania pierwszych serii lokomotyw elektrycznych prądu stałego (lokomotywy ВЛ19-17 oraz C11-18), natomiast w okresie od grudnia 1939 roku do lata $1940 \mathrm{roku}$, na okręgu doświadczalnym w Szczerbince przeprowadzono badania pierwszego, wyproduko- 
wanego w ZSRR, pojazdu trakcyjnego zasilanego prądem przemiennym o napięciu $20 \mathrm{kV}$ i częstotliwości przemysłowej $50 \mathrm{~Hz}$ (lokomotywa serii OP22) [18].

W latach 1936-1937, na okręgu w Szczerbince przeprowadzono pierwsze badania dynamiczne czteroosiowych wagonów towarowych oraz czteroosiowych wagonów pasażerskich [7]. Warto wskazać, że tor doświadczalny umożliwił prowadzenie badań elementów infrastruktury kolejowej. Na przełomie lat trzydziestych i czterdziestych XX wieku, w związku z podjętą elektryfikacją sieci kolejowej, szczególnie ważne były badania elektrycznych pojazdów trakcyjnych, a także badania elementów systemu zasilania elektroenergetycznego. Warto również wspomnieć, że na początku 1941 roku całkowita długość linii zelektryfikowanych w ZSRR wynosiła $1800 \mathrm{~km}$ [7]. W latach pięćdziesiątych XX wieku na okręgu w Szczerbince podjęto badania sił podłużnych powstających przy hamowaniu pociągu towarowego o masie 8000 ton [27], natomiast w latach 1965-1966 przeprowadzono badania hamowania elektropneumatycznego jednorodnego składu pociągu o masie 10000 ton.

W latach 1958-1959 poligon badawczy w Szczerbince został znacząco rozbudowany. Powstały wówczas dwa następne okręgi badawcze charakteryzujące się bardziej zróżnicowanym układem geometrycznym w płaszczyźnie poziomej i pionowej [27]. Okrąg doświadczalny w Szczerbince pod Moskwą jest najbardziej znanym poligonem WNIIŻT i obecnie jest wyposażony w 3 tory w kształcie pętli (rys. 4):

- Tor nr 1 jest na całej długości poziomy, położony w łuku o stałym promieniu $956 \mathrm{~m}$, a jego długość wynosi $6,0 \mathrm{~km}$. Jest przeznaczony do badań elektrycznych i spalinowych pojazdów trakcyjnych, wagonów pasażerskich oraz wagonów towarowych, układów hamulcowych, sieci trakcyjnej (rys. 5).

- Tory nr 2 i 3 o długości 5,7 km, są położone w łukach o promieniach $390-1200 \mathrm{~m}$ i pochyleniach podłużnych do $12 \%$; przeznaczone są do badań trwałości nawierzchni oraz wagonów towarowych. $\mathrm{W}$ torze 3 znajduje się estakada z przęsłami o długości do $66 \mathrm{~m}$.

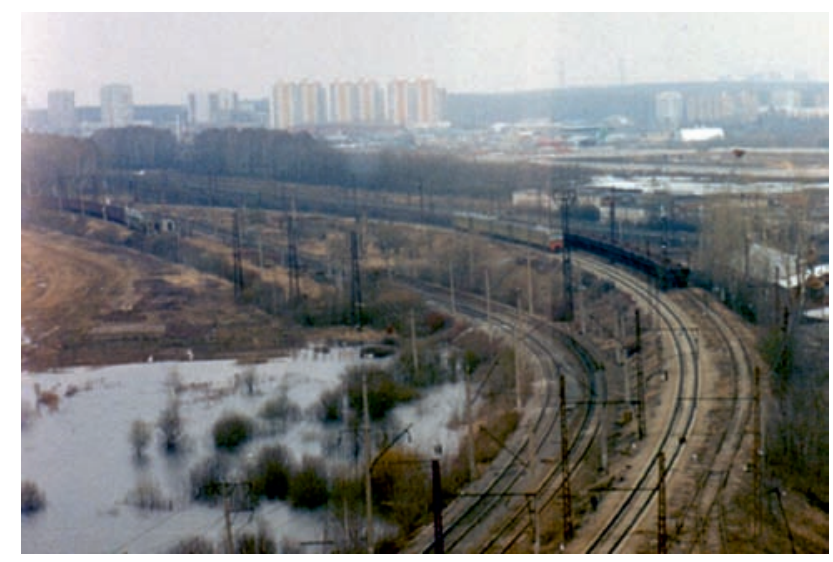

Rys. 4. Tory okręgu doświadczalnego WNIIŻT w Szczerbince widok z budynku administracyjnego [fot. A. Massel, 1999 r.]

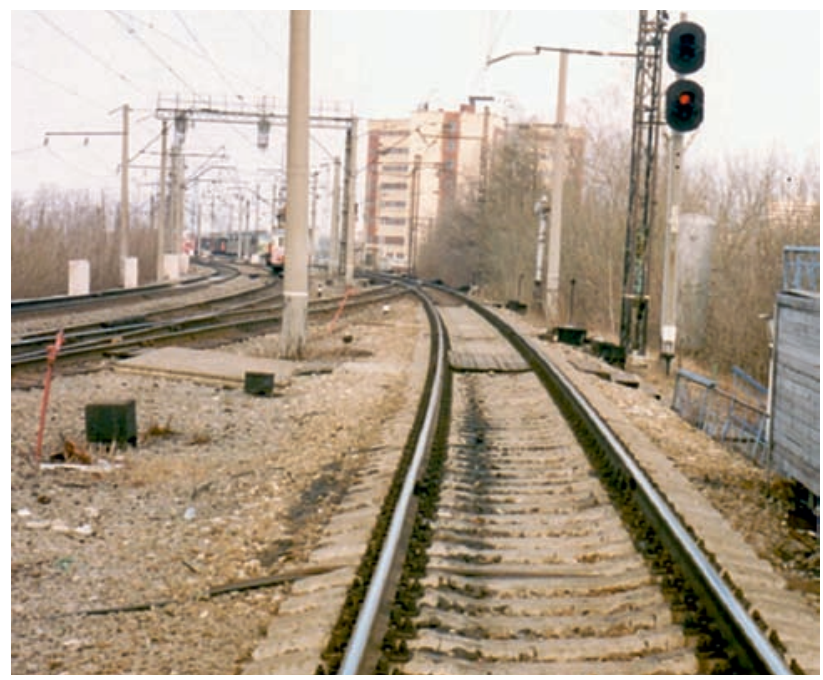

Rys. 5. Nawierzchnia w torze nr 1 okręgu doświadczalnego w Szczerbince [fot. A. Massel, 1999 r.]

Tory na okręgu doświadczalnym w Szczerbince mogą być zasilane napięciem $25 \mathrm{kV}$ prądu przemiennego oraz napięciem $3 \mathrm{kV}$ i $825 \mathrm{~V}$ prądu stałego. Maksymalna prędkość w torze $\mathrm{nr} 1$ dla pociagów pasażerskich wynosząca początkowo $120 \mathrm{~km} / \mathrm{h}$, była następnie zwiększona do $140 \mathrm{~km} / \mathrm{h}$. Maksymalna prędkość dla pociągów towarowych kursujących po tym torze wynosi $90 \mathrm{~km} / \mathrm{h}$.

Okrąg doświadczalny stanowi jedyną w swoim rodzaju bazę do badań konstrukcji nawierzchni kolejowej i podtorza. Zapewniono na nim realne warunki pracy toru, maksymalnie zbliżone do rzeczywistej eksploatacji, przy równoczesnym zapewnieniu wysokiej dokładności uzyskiwanych wyników. Do prowadzenia badań nawierzchni oraz jej elementów wykorzystuje się dwa tory (nr 2 i 3), w których zabudowane są różne konstrukcje nawierzchni do badań i oceny między innymi różnych wariantów kształtu pryzmy podsypki, typów podkładów, a także podpór blokowych. Badaniom podlegają partie szyn dostarczonych przez różnych producentów. Ważnym obszarem badań nawierzchni kolejowych prowadzonych na okręgu doświadczalnym było także określenie wpływu zwiększenia nacisków osi z 22 do 27 ton, a następnie do 30 ton na występowanie i rozwój wad kontaktowo-zmęczeniowych szyn [7].

Interesujący jest fakt, że w latach 1987-1995 na okręgu doświadczalnym w Szczerbince przeprowadzono badania trwałości polskiego systemu przytwierdzenia SB3 w trudnych warunkach eksploatacyjnych. Badania te prowadzono na odcinku o długości $162,5 \mathrm{~m}$, położonym w łuku o promieniu $600 \mathrm{~m}$. Podstawowym celem badań było określenie rodzaju i liczby uszkodzeń części składowych przytwierdzenia do przeniesienia obciążenia $800 \mathrm{Tg}$. Po osiągnięciu tego obciążenia, badania przedłużono i sumaryczne obciążenie wyniosło aż $2184,3 \mathrm{Tg}$. W 1995 roku 
wyjęto $\mathrm{z}$ toru badaną konstrukcję, a przeniesione obciążenie rosyjscy specjaliści uznali za rekordowy wynik w historii okręgu doświadczalnego, nigdy wcześniej nie uzyskany [13].

W ostatnich latach, na okręgu były badane na przykład szyny produkcji austriackiej i japońskiej, a także różne typy przytwierdzeń szyn (ARS, ŻBR, Pandrol, Vossloh). Prowadzono badania rozjazdów z nowymi konstrukcjami krzyżownic, a także podkładów betonowych różniących się sposobem zbrojenia. $\mathrm{Na}$ wybranych odcinkach toru testowano różne rozwiązania techniczne, takie jak absorbery montowane na szyjkach szyn, sklejanie podsypki, podkładki podpodkładowe i przekładki podszynowe. W związku z planowaną budową linii dużych prędkości Moskwa - Kazań, na okręgu w Szczerbince przeprowadzono badania konstrukcji nawierzchni bezpodsypkowej: LVT (Rosja), Max Bögl (Niemcy), Alstom (Francja), Tines (Polska). W trakcie badań tych nawierzchni zostało przeniesione obciążenie $600 \mathrm{Tg}$.

Warto podkreślić, że do badań trwałościowych wykorzystywano ciężki pociąg towarowy o masie 10 tysięcy ton i nacisku osi 30 ton. Umożliwia to przeniesienie obciążenia rzędu 300 milionów ton (Tg) rocznie, co w porównaniu z badaniami na eksploatowanych liniach kolejowych, umożliwia skrócenie czasu badań nawet od 8 do 10 razy.

$\mathrm{Na}$ okręgu w Szczerbince znajduje się estakada doświadczalna, którą przekazano do użytkowania w 1977 roku. Powstała ona w celu wykonywania badań przęseł mostowych różnych typów o rozpiętości do $66 \mathrm{~m}$, konstrukcji jezdni, a także podpór zarówno nowych, jak już eksploatowanych na liniach kolejowych. Celem różnorodnych badań prowadzonych z wykorzystaniem estakady, było określenie żywotności nowych typów przęseł oraz ich poszczególnych elementów, określenie czasu możliwej eksploatacji przęseł wyjętych $\mathrm{z}$ toru, a także opracowanie nowych konstrukcji przęseł charakteryzujących się większą trwałością zmęczeniową i obliczonych na dłuższy czas pracy, wymagających mniejszych nakładów na utrzymanie [14]. Dzięki badaniom, w przyspieszonym trybie było możliwe ujawnienie wad konstrukcji nawet 10 razy szybciej niż w normalnej eksploatacji. W czasie od 1975 do 1990 roku, na estakadzie prowadzono badania 11 różnych konstrukcji przęseł. Przeniesione w tym czasie obciążenie wyniosło ponad $2300 \mathrm{Tg}$. Po zakończeniu tego cyklu badawczego, estakada doświadczalna została wyłączona $\mathrm{z}$ trasy, po której kursuje ciężki pociąg towarowy.

Poza okręgiem doświadczalnym $\mathrm{w}$ Szczerbince, WNIIŻT dysponuje torem doświadczalnym Biełorieczenskaja-Majkop. Ten odcinek doświadczalny utworzono w latach sześćdziesiątych $\mathrm{XX}$ wieku, w celu umożliwienia oceny właściwości dynamicznych pojazdów szynowych i ich oddziaływania na nawierzch- nię, także przy zwiększonych prędkościach jazdy. W wyniku szczegółowej analizy różnych odcinków na sieci kolejowej byłego ZSRR, wybrano lokalizację tego poligonu na odcinku mało obciążonej linii Biełorieczenskaja-Majkop na Kolei Północno-Kaukaskiej. Znajduje się on na terenie autonomicznej republiki Adygei, wchodzącej w skład Federacji Rosyjskiej. Za wyborem tej konkretnej lokalizacji przemawiały następujące przesłanki [22]:

- stacja Biełorieczenskaja jest stacją węzłową w miejscu styku dwóch systemów zasilania: $3 \mathrm{kV}$ i $25 \mathrm{kV}$, co umożliwia prowadzenie badań taboru zarówno przy zasilaniu prądem stałym, jak i przemiennym;

- korzystne warunki klimatyczne na północnym Kaukazie, umożliwiające prowadzenie badań także w okresie zimowym (pryzma podsypki nie zamarza);

- małe obciążenie odcinka przewozami, co umożliwia założenie od 8 do 10 godzinnych przerw w ruchu w celu prowadzenia badań w porze dziennej.

W wyniku przebudowy odcinka Biełorieczenskaja-Majkop, powstał poligon doświadczalny, który umożliwił prowadzenie badań wszelkich typów pojazdów z prędkościami do $250 \mathrm{~km} / \mathrm{h}$, pozwalając badać tabor na odcinkach prostych oraz w łukach o różnych promieniach, a także na rozjazdach. Długość jednotorowego odcinka (liczona od semafora wjazdowego do stacji Biełorieczenskaja do semafora wjazdowego stacji Majkop) wynosi około $24 \mathrm{~km}$. Odcinek zelektryfikowano prądem stałym oraz przemiennym i wyposażono w półsamoczynną przekaźnikową blokadę liniową. Na odcinku jest zlokalizowana jedna stacja pośrednia Chanskaja, przy której zbudowano trójkąt torowy przeznaczony do obracania badanych składów, natomiast na stacji Biełorieczenskaja znajdują się tory do odstawiania składów oraz budynek, w którym wykonywane są oględziny techniczne taboru, a także przygotowanie pojazdów do badań.

Tor główny na szlakach Biełorieczenskaja - Chanskaja i Chanskaja - Majkop został ogrodzony i obsadzony roślinnością $\mathrm{w}$ celu zabezpieczenia przed wtargnięciem zwierząt. Na odcinku doświadczalnym zlokalizowane są łuki poziome o różnych promieniach: 350 m, 500 m, 650 m, 800 m, 1000 m, 2050 m. Łuki są zlokalizowane przede wszystkim na szlaku Majkop Chanskaja, natomiast na szlaku od stacji Chanskaja do stacji Biełoreczenskaja znajduje się bardzo długi prosty odcinek, umożliwiający prowadzenie jazd z prędkością do $250 \mathrm{~km} / \mathrm{h}$. Odcinek charakteryzuje się także dogodnym układem geometrycznym w płaszczyźnie pionowej. Średnie wzniesienie na szlaku Biełorieczenskaja - Chanskaja wynosi 3,1\%o, na szlaku Chanskaja - Majkop zaś 3,7\%o [22]. W czasie badań, jazdy doświadczalne taboru odbywają się po torze głównym zasadni- 
czym stacji Chanskaja. W torze tym znajdują się rozjazdy o typowym dla kolei rosyjskich skosie 1:11. W czasie badań tor jest traktowany jako część długiego szlaku od stacji Biełorieczenskaja do stacji Majkop.

Pod koniec minionego dziesięciolecia XXI w., odcinek doświadczalny zmodernizowano. Potrzeba modernizacji wynikała $\mathrm{z}$ konieczności przeprowadzenia badań elektrycznych zespołów trakcyjnych dużych prędkości (Sapsan), wyprodukowanych w Niemczech dla kolei rosyjskich. Na odcinku Biełorieczenskaja Majkop wybudowano ponad 600 nowych konstrukcji wsporczych, wymieniono sieć trakcyjną, a także linie zasilające, przy czym nadal zapewniono możliwość zasilania linii Wschodnio-Europejskiej (LGV Est européenne) zarówno prądem stałym, jak i przemiennym. Ukształtowanie toru w płaszczyźnie poziomej i pionowej, system zasilania, sieć trakcyjna i urządzenia sterowania ruchem umożliwiają prowadzenie następujących badań taboru kolejowego [27]:

- oddziaływania na elementy konstrukcji nawierzchni torów i rozjazdów,

- dynamicznych,

- wytrzymałościowych,

- hamulców,

- aerodynamicznych,

- wzajemnego oddziaływania różnych typów sieci trakcyjnej i pantografów,

- współczynnika przyczepności kół i szyn oraz

- określenia oporów ruchu.

Podsumowując, można wskazać następujące cechy szczególne odcinka doświadczalnego Biełorieczenskaja-Majkop:

- dwa systemy zasilania,

- lokalizacja na linii o małym obciążeniu ruchem,

- ciepły klimat, umożliwiający prowadzenie badań przez cały rok,

- występowanie długich odcinków prostych i łuków o zróżnicowanych promieniach,

- zaplecze do przygotowywania obiektów do badań,

- baza hotelowa dla zespołów badawczych.

\subsection{Okrąg doświadczalny CARS (Chiny)}

Poligon badawczy China National Railway Testing Center Dongjiao (rys. 6) należy do China Academy of Railway Sciences. Obiekt jest zlokalizowany $20 \mathrm{~km}$ na wschód od Pekinu. Pierwszy etap jego budowy był realizowany w latach 1958-1960. W obiekcie znajdują się tory o całkowitej długości około $38 \mathrm{~km}$, wszystkie tory są zelektryfikowane. W skład poligonu wchodzi główny okrąg doświadczalny Huanxing Tielu, istniejący od 1958 roku. Długość okręgu wynosi $9 \mathrm{~km}$, promień łuku $1433 \mathrm{~m}$. Ponadto, na poligonie znajduje się kilka torów dodatkowych o różnych krzywiznach oraz odcinek prosty o długości 1,6 km [4].

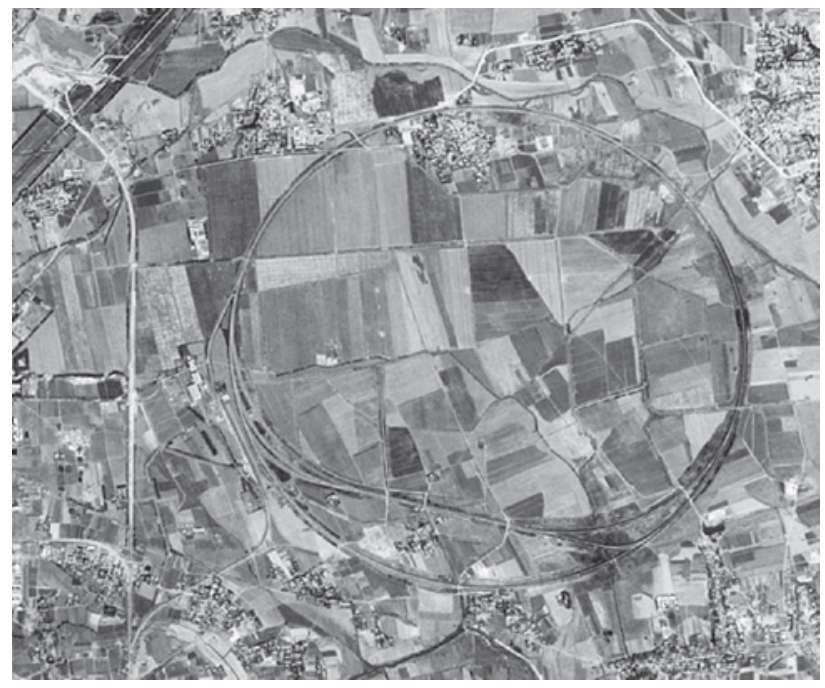

Rys. 6. Zdjęcie satelitarne okręgu doświadczalnego CARS pod Pekinem [1967 rok]

Układ geometryczny okręgu zaprojektowano $\mathrm{w}$ ten sposób, aby na potrzeby przejazdów pociągami można było wykorzystywać łuki o promieniach 200, 350, 600, 800, 1000 i $1433 \mathrm{~m}$. Maksymalne prędkości określono na poziomie [4]:

- $120 \mathrm{~km} / \mathrm{h}$ na prostej,

- $\quad 80-90 \mathrm{~km} / \mathrm{h}$ na łuku o promieniu $R=350 \mathrm{~m}$ i przechyłce $h=104 \mathrm{~mm}$,

- $90 \mathrm{~km} / \mathrm{h}$ na łuku o promieniu $R=600 \mathrm{~m}$ i przechyłce $h=80 \mathrm{~mm}$.

Wszystkie tory zelektryfikowano prądem przemiennym o napięciu $25 \mathrm{kV}$. Okrąg przeznaczono przede wszystkim na potrzeby badań trakcyjnych lokomotyw, hamulców, oddziaływań koło - szyna oraz badań różnych konstrukcji nawierzchni i jej części składowych [4].

\subsection{Okrąg doświadczalny VUZ w Velimiu (Czechy)}

Ośrodek badawczy w Velimiu należy do Kolejowego Instytutu Badawczego VUZ (Výzkumný Ústav Železniční, a.s.) i od 1 lipca 2005 roku jest spółką zależną Kolei Czeskich (CD). Ośrodek jest zlokalizowany w miejscowości Cerhenice ( $\mathrm{w}$ rejonie miasta Poděbrady) i połączony ze stacją kolejową Velim na odcinku Praga - Kolin. Ośrodek VUZ dysponuje dwoma okręgami doświadczalnymi [28].

Pierwsze plany zbudowania okręgu doświadczalnego były opracowywane $\mathrm{w}$ drugiej połowie lat pięćdziesiątych XX wieku. W 1959 roku, na konferencji ministrów komunikacji krajów RWPG, wskazano potrzebę stworzenia bazy doświadczalnej umożliwiającej przeprowadzanie kompleksowych badań pojazdów szynowych. Za przygotowanie inwestycji i jej realizację były odpowiedzialne ówczesne Czechosło- 
wackie Koleje Państwowe (CSD). Pierwszym krokiem było ustalenie lokalizacji okręgu badawczego, a także ustalenie jego podstawowych parametrów. Przyjęto, że układ geometryczny powinien umożliwiać osiąganie prędkości jazd doświadczalnych do $200 \mathrm{~km} / \mathrm{h}$. Rozważano sześć możliwych lokalizacji: Vrútky, Velim, Jíkev, Vraňany, Nýřany oraz Diviaky (lokalizacje zarówno na terenie obecnej Republiki Czeskiej oraz Republiki Słowackiej). Jako najwłaściwsze wybrano umiejscowienie toru doświadczalnego na terenie gmin Velim, Sokoleč, Vrbová Lhota oraz Ratenice - na północ od linii kolejowej Praga - Kolin, w terenie równinnym, przeciętym stosunkowo mało obciążonymi drogami kołowymi. Taki wybór umożliwiał ograniczenie robót ziemnych przy budowie toru. Budowę podzielono na trzy etapy (zadania) [5]:

1) budowa dużego okręgu doświadczalnego (VZO) wraz bocznicą do stacji Velim, zrealizowana do lipca 1963 roku,

2) elektryfikacja dużego okręgu doświadczalnego w systemie $3 \mathrm{kV}$ prądu stałego i $25 \mathrm{kV}$ prądu przemiennego, zrealizowana do października 1965 roku (podjęcie ruchu trakcją elektryczną 14 grudnia 1965 r.),

3) budowa małego okręgu doświadczalnego (MZO), wraz z jego elektryfikacją, budową torów bocznych o długości $650 \mathrm{~m}$ i $850 \mathrm{~m}$, budową budynków zaplecza administracyjnego, a także suwnic bramowych o nośności 3 tony oraz 5 ton, rozpoczęta w 1969 roku, a ukończona w czerwcu 1971 roku.

Na dużym okręgu została zabudowana nawierzchnia bezstykowa, ze stosowanymi wówczas szynami R65 (standardowy typ szyny na kolejach ZSRR) ułożonymi na podkładach betonowych (pochylenie poprzeczne szyn 1:20), a na odcinku od $\mathrm{km} \mathrm{0,0}$ do $\mathrm{km} \mathrm{1,45} \mathrm{-} \mathrm{na}$ podkładach drewnianych (pochylenie poprzeczne szyn 1:40). Od razu założono, że duży okrąg będzie służył do prowadzania badań taboru przy zwiększonych prędkościach jazdy. Pierwotnie na tym okręgu obowiązywała prędkość maksymalna $180 \mathrm{~km} / \mathrm{h}$ [5].

Mały okrąg w początkowym okresie eksploatacji był bardzo intensywnie wykorzystywany do prowadzenia badań trwałościowych różnych konstrukcji nawierzchni kolejowej. Badania takie realizowano przede wszystkim $\mathrm{w}$ latach siedemdziesiątych XX wieku. Do momentu pierwszej naprawy głównej toru MZO, wykonanej w 1985 roku, całkowite przeniesione obciążenie brutto wyniosło 925 milionów ton $(925 \mathrm{Tg})$. Przeciętna masa pociągu wyniosła przy tym 2865 ton, chociaż w niektórych jazdach wykorzystywano pociąg o masie do 4000 ton.

$\mathrm{W}$ późniejszych latach powstały kolejne obiekty Ośrodka, w tym stanowisko do badań dynamicznych (DZS), zbudowane w latach 1986-1991, a także hala przeznaczona do przygotowywania taboru do badań zrealizowana w 2002 roku. Na dużym okręgu VZO zainstalowano w 2004 roku, urządzenia przytorowe systemu bezpiecznej kontroli jazdy ETCS poziomu 1 [5]. W następnym roku, na okręgu (oraz na przyległym odcinku linii kolejowej Děčín - Praga - Kolín) uruchomiono urządzenia systemu GSM -R. W 2005 roku na okręgu doświadczalnym zabudowano nowe rozjazdy, a w 2006 roku rozpoczęto kompleksową wymianę nawierzchni kolejowej na dużym okręgu. Prace te umożliwiły zwiększenie maksymalnej prędkości na dużym okręgu (VZO) z $200 \mathrm{~km} / \mathrm{h}$ do $210 \mathrm{~km} / \mathrm{h}$ dla taboru konwencjonalnego i $230 \mathrm{~km} / \mathrm{h}$ dla taboru $\mathrm{z}$ wychylnym nadwoziem [5].

Dalsza modernizacja ośrodka w Velimiu była współfinansowana ze środków Unii Europejskiej. Jej pierwszy etap dotyczył przede wszystkim zasilania trakcyjnego i obejmował między innymi budowę nowej podstacji trakcyjnej ze zwiększeniem maksymalnej mocy przy zasilaniu prądem stałym do 10 MVA. W drugim etapie wymieniono sieć trakcyjną na sieć zgodną z TSI ENE, o prędkości maksymalnej $250 \mathrm{~km} / \mathrm{h}$. Powstała także nowa hala o długości $144 \mathrm{~m}$, przeznaczona do przygotowywania taboru do badań, a dwie istniejące hale zmodernizowano. $\mathrm{W}$ tym etapie zbudowano również peron o długości $230 \mathrm{~m}$, przeznaczony do badań aerodynamicznych [24]. W 2012 roku podjęto decyzję o rozpoczęciu kolejnego etapu modernizacji ośrodka, w ramach którego wydłużono halę $\mathrm{nr} 2$ do $200 \mathrm{~m}$, a halę nr 1 do $120 \mathrm{~m}$. Duży okrąg został wyposażony w urządzenia ETCS poziomów 1 i 2 . Zabudowę tych urządzeń zrealizowała firma AŽD Praha.

Duży okrąg VZO o długości 13,276 km składa się $\mathrm{z}$ dwóch łuków o promieniu $1400 \mathrm{~m}$ oraz z dwóch odcinków prostych o długości $2 \mathrm{~km}$ (rys. 7). Maksymalna prędkość wynosi $210 \mathrm{~km} / \mathrm{h}$ dla taboru konwencjonalnego i $230 \mathrm{~km} / \mathrm{h}$ dla taboru $\mathrm{z}$ wychylnym nadwoziem [5].

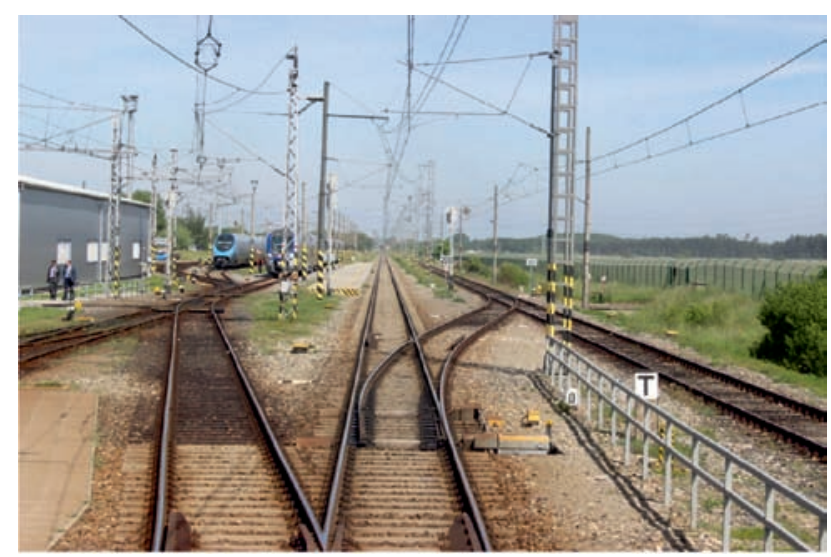

Rys. 7. Okrąg doświadczalny VUZ w Velimiu- odcinek prosty $\mathrm{z}$ rozjazdami oraz stacja techniczna [fot. A. Massel]

Mały okrąg MZO ma długość 3,951 km. Na tym okręgu znajdują się łuki o promieniach $300 \mathrm{~m}, 450 \mathrm{~m}$, 
$600 \mathrm{~m}$ i $800 \mathrm{~m}$. Na części tego toru ułożono nawierzchnię bezstykową, na pozostałej zaś nawierzchnię klasyczną. Zabudowane zostały przy tym różne typy szyn: R65, UIC60, S49. Maksymalna prędkość na okręgu MZO wynosi od $85-120 \mathrm{~km} / \mathrm{h}$ (w zależności od promienia łuku). Całkowita długość torów (według stanu na 2006 rok) w Ośrodku wynosiła $28,218 \mathrm{~km}$ [5]. Dopuszczalny nacisk osi na poszczególnych torach wynosi zasadniczo 22,5 tony, a przy jazdach odbywających się pod specjalnym nadzorem - 25 ton. Okręgi doświadczalne w Velimiu są przeznaczone do badań taboru kolejowego dla różnych kolei w Europie, dlatego są one zelektryfikowane, przy czym istnieje możliwość zasilania zarówno w systemach prądu przemiennego $25 \mathrm{kV}$ i $15 \mathrm{kV}$, jak i w systemach prądu stałego $3 \mathrm{kV}$ i $1,5 \mathrm{kV}$.

Ośrodek badawczy w Velimiu jest wyposażony w urządzenia Europejskiego Systemu Zarządzania Ruchem Kolejowym (ERTMS). Instalacja zabudowana $\mathrm{w}$ ramach wspomnianego projektu modernizacyjnego pozwala na wykonywanie badań z wykorzystaniem urządzeń różnych poziomów ETCS: L1, L2, LSTM (typu LS) oraz L0. Umożliwia symulowanie określonych warunków występujących na linii, na przykład ograniczeń prędkości, konieczności opuszczenia pantografów itp. Możliwe jest także testowanie przejścia pomiędzy poszczególnymi systemami (ogółem 6 różnych kombinacji) [5]. Na torach ośrodka VUZ możliwe jest wykonywanie wszystkich badań pojazdów szynowych. W szczególności są to następujące badania [5]:

- bezpieczeństwa jazdy i właściwości biegowych,

- trakcyjne,

- hamulców,

- hałasu i drgań,

- elektryczne w zakresie wysokich napięć - badania systemów zasilania pojazdów szynowych, badania wyposażenia elektrycznego i pantografów,

- elektryczne w zakresie niskich napięć - badania wpływu na środowisko, badania kompatybilności elektromagnetycznej,

- wytrzymałościowe i zmęczeniowe.

W kwietniu 2017 roku zmienił się status prawny czeskiego okręgu doświadczalnego. Znowelizowana ustawa o kolejach ( $\$ 3$, ust.1) wprowadziła nową kategorię kolei doświadczalnej (Zkušební dráha). Wcześniej, infrastruktura torowa VUZ pod względem formalno-prawnym była traktowana jako bocznica [9].

\subsection{Poligony badawcze Transport Technology Center w Pueblo (USA)}

Centrum Technologii Transportowych (Transport Technology Center) powstało w 1971 roku jako agenda Federalnej Administracji Kolei (Federal Railroad Administration - FRA). W 1982 roku Centrum zosta- ło przekazane Stowarzyszeniu Kolei Amerykańskich AAR. Zlokalizowane jest ono w pobliżu Pueblo w stanie Colorado, gdzie zajmuje obszar 52 mil kwadratowych $\left(134,7 \mathrm{~km}^{2}\right)$ i zapewnia możliwość prowadzenia badań oraz prac rozwojowych dotyczących różnych systemów transportowych zarówno na potrzeby sektora państwowego, jak i prywatnego. Na terenie Centrum znajdują się tory badawcze o łącznej długości 48 mil $(77,2 \mathrm{~km})$. Są to następujące tory:

1. HTL (High Tonnage Loop) - okrąg doświadczalny o długości 2,7 mili (4,3 km), przeznaczony do badań elementów nawierzchni kolejowej przy dużych obciążeniach. Na okręgu znajdują się 3 łuki o promieniu $349 \mathrm{~m}$ (5 stopni) oraz jeden łuk o promieniu $291 \mathrm{~m}$ (6 stopni), maksymalna prędkość wynosi $40 \mathrm{mil}$ na godzinę $(64 \mathrm{~km} / \mathrm{h})$.

2. WRM (Wheel Rail Mechanism) - okrąg doświadczalny o długości 3,5 mili $(5,6 \mathrm{~km})$ przeznaczony do badań zachowania się taboru na torze o bardzo dobrym układzie geometrycznym, a także na torze z celowo wprowadzonymi nierównościami.

3. RTT (Railroad Test Track) - duży okrąg doświadczalny o długości 13,5 mili $(21,7 \mathrm{~km})$, na którym znajdują się łuki o dużych promieniach, przy czym minimalny promień wynosi około $1750 \mathrm{~m}$ (1 stopień) przy przechyłce 6 cali $(152 \mathrm{~mm})$. Na okręgu są zabudowane szyny spawane o masie 136 funtów na jard $(68 \mathrm{~kg} / \mathrm{m})$, nowe podkłady betonowe, a także podkłady $\mathrm{z}$ drewna twardego $\mathrm{z}$ przytwierdzeniem sprężystym. Tor jest zelektryfikowany prądem przemiennym o napięciu $12,5,25$ oraz $50 \mathrm{kV}$ (o częstotliwości $60 \mathrm{~Hz}$ ), przy czym istnieje także możliwość zasilania sieci prądem stałym. Maksymalna prędkość na tym torze wynosi 165 mil na godzinę $(265 \mathrm{~km} / \mathrm{h})$. Tor RRT jest przeznaczony do wszelkich badań dynamicznych taboru, zwłaszcza przy dużych prędkościach jazdy (rys. 8).

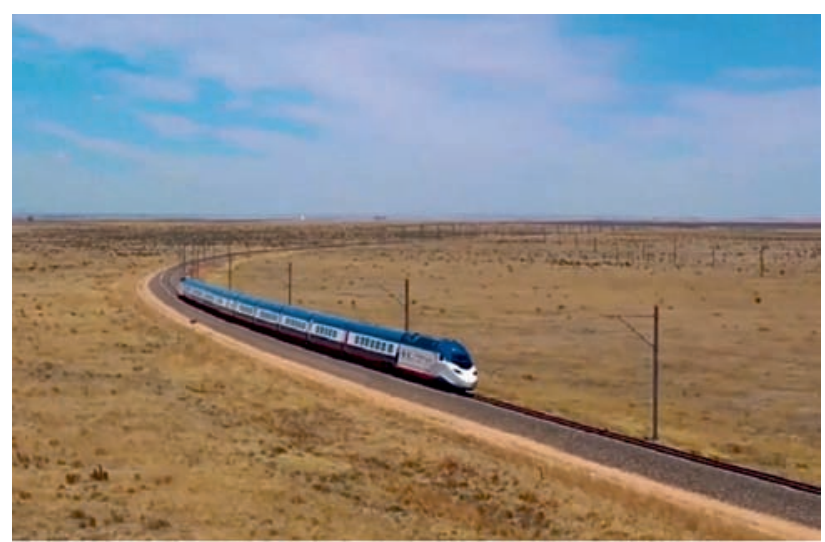

Rys. 8. Badania elektrycznego zespołu trakcyjnego Avelia Liberty przeznaczonego dla Amtrak na okręgu RTT [źródło: Amtrak]

4. TTT (Transit Test Track) - okrąg doświadczalny o długości 9,1 mili (14,6 km), wyposażony w zasi- 
lanie z trzeciej szyny, przeznaczony do badań homologacyjnych taboru do ruchu na kolejach miejskich i podmiejskich, a także na sieciach metra.

5. IT (Impact Track) - tor o długości 0,75 mili $(1,2 \mathrm{~km})$ przeznaczony do badań zderzeniowych, w tym zderzeń pociągów w skali 1:1.

6. PTT (Precision Test Track) - tor o długości 6,2 mili $(10,0 \mathrm{~km})$ wykorzystywany przede wszystkim do badań dynamicznych, potwierdzania zgodności $\mathrm{z}$ wymaganiami bezpieczeństwa oraz do badań zderzeniowych.

7. TDT (Train Dynamics Track) - tor do badań dynamicznych, na którym znajduje się łuk o promieniu $1167 \mathrm{~m}\left(1^{\circ} 30^{\prime}\right)$.

Badania o trwałościowym charakterze są prowadzone na poligonie o nazwie FAST (Facility for Accelerated Service Testing), umożliwiającym znaczące przyspieszenie badań eksploatacyjnych. Zasadnicza częścią poligonu jest okrąg doświadczalny HTL (High Tonnage Loop), na którym w 1986 roku podjęto badawczy program HAL (Heavy Axleload), ukierunkowany na wprowadzenie zwiększonych nacisków osi do praktyki eksploatacyjnej kolei amerykańskich.

Na okręgu HTL odbywają się przejazdy pociągu ciężkiego, który składa się od 110 do 115 wagonów towarowych o masie brutto 142,7 tony każdego wagonu i jest prowadzony trzema lokomotywami spalinowymi z prędkością $64 \mathrm{~km} / \mathrm{h}$. Ruch na torze HTL jest dwukierunkowy, przy czym udział przejazdów w każdym kierunku wynosi po 50\%. Dzięki wykorzystaniu w badaniach bardzo ciężkiego pociągu jest możliwe bardzo szybkie uzyskiwanie wyników. Na przykład podczas badań prowadzonych w 2010 roku [21] każdego dnia było przenoszone obciążenie wynoszące około 1,55 miliona ton.

Przykładem badań nawierzchniowych wykonywanych na okręgu w Pueblo były badania dwóch typów nawierzchni bezpodsypkowej, to jest nawierzchni z przytwierdzeniem bezpośrednim (DFST) oraz nawierzchni z podwójnymi podporami blokowymi (IDBT). W lipcu 2003 roku każda z tych konstrukcji została zabudowana na odcinku toru o długości 250 stóp (około $75 \mathrm{~m}$ ), położonym w łuku o promieniu $349 \mathrm{~m}$, przy czym połączenie z przyległym torem na podsypce znajdowało się na długości krzywych przejściowych. W ciągu trzech lat przeniesiono obciążenie przekraczające 170 milionów ton amerykańskich (około $154 \mathrm{Tg}$ ), przy czym tor nadal mógł być eksploatowany, odchyłki geometryczne zaś nie przekraczały wartości dopuszczalnych dla toru klasy 9 według FRA (klasa 9 jest najwyższą klasą toru, a dopuszczalna prędkość wynosi 200 mil na godzinę) [6].

Ważny i bardzo reprezentatywny przykład badań trwałościowych, wykonywanych na okręgu HTL w Transport Technology Center, stanowią badania szyn przeznaczonych do stosowania na liniach o dużym obciążeniu przewozami. Badania takie podjęto w 2010 roku i objęły ocenę zużycia i właściwości zmęczeniowych szyn o różnej twardości. Poddano im 10 rodzajów szyn o dużej twardości dostarczonych przez 7 producentów [21]. Wszystkie szyny o dużej twardości (średnia twardość $407 \mathrm{HB}$ ) zabudowano w łuku o promieniu $349 \mathrm{~m}$, z przechyłką $100 \mathrm{~mm}$, eksploatowanym bez smarowania. Łączna długość odcinka badawczego wynosiła $320 \mathrm{~m}$. Ponadto prowadzi się analogiczne badania szyn o przeciętnej twardości (IH - Intermediate Hardness), które objęły szyny ośmiu rodzajów dostarczone przez sześciu producentów. Przeciętna twardość dla tej grupy szyn wynosiła $335 \mathrm{HB}$. Te szyny również zabudowano na odcinku o długości $244 \mathrm{~m}$ położonym w łuku o promieniu $349 \mathrm{~m}$ i przechyłce $100 \mathrm{~mm}$, jednak w tym przypadku szyny były smarowane. Pierwsze serie badań zużycia zostały wykonane po przejściu obciążenia: 29,2 oraz 54,7 , a także 81,1 milionów ton a całość badań zaplanowano na 3-4 lata [21].

$\mathrm{Na}$ okręgu HTL zainstalowano różne konstrukcje przęseł mostowych (rys. 9). Pierwszy stalowy most z nawierzchnią bezpodsypkową został zainstalowany na okręgu HTL w 1997 roku. Wśród zabudowanych wtedy przęseł było między innymi przęsło stalowe (wyprodukowane w 1957 roku), które w okresie od 1997 do 2013 roku przeniosło obciążenie wynoszące $1911 \mathrm{Tg}$ [17].

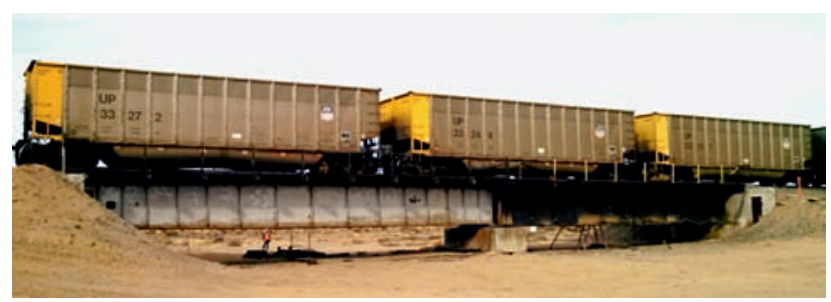

Rys. 9. Jeden z mostów na poligonie FAST w Pueblo [źródło: TTC]

W 2018 roku TTCI prowadziło badania zmęczeniowe pięciu nitowanych przęseł mostowych ze stalowymi dźwigarami blachownicowymi oraz dwóch przęseł betonowych. Celem tych badań było wydłużenie okresu bezpiecznego użytkowania przęseł. Inne testy dotyczące mostów, które są realizowane na poligonie FAST, to testy elementów jezdni mostów, alternatywnych konstrukcji mostownic, nowych systemów przytwierdzenia na mostach z nawierzchnią bezpodsypkową oraz rozwiązań technicznych stosowanych $\mathrm{w}$ strefie przejściowej pomiędzy nawierzchnią torową na nasypie i nawierzchnią na konstrukcji mostowej [17].

$\mathrm{Na}$ poligonie $\mathrm{w}$ Pueblo prowadzone są badania systemów sterowania i łączności. Zainstalowane są urządzenia wszystkich systemów transmisji danych i komunikacji głosowej, stosowanych na dużych sie- 
ciach kolejowych w USA (tzw. Class I). W ośrodku w Pueblo znajduje się też instalacja testowa do badań urządzeń systemu bezpiecznej kontroli jazdy PTC (Positive Train Control), który jest obecnie wdrażany na kolejach amerykańskich na mocy ustawy o poprawie bezpieczeństwa na kolejach (Railway Safety Improvement Act) z 2008 roku.

\subsection{Okrąg doświadczalny AFER w Faurei (Rumunia)}

Poligon doświadczalny kolei rumuńskich powstał w 1978 roku. Został on zbudowany na potrzeby ówczesnego Instytutu Projektowo-Badawczego Transportu (ICPTT), obecnie zaś należy do AFER - krajowego organu bezpieczeństwa $\mathrm{w}$ transporcie kolejowym stanowiąc Ośrodek Badań Kolejowych (CTF) Poligon jest zlokalizowany w pobliżu stacji węzłowej Faurei, około $130 \mathrm{~km}$ na północny wschód od Bukaresztu (rys. 10).

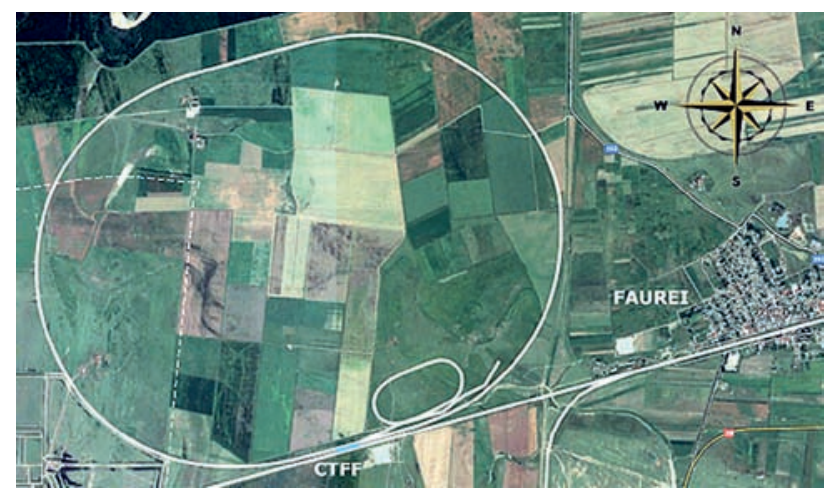

Rys. 10. Okrąg doświadczalny AFER w Faurei (źródło: AFER)

Zasadniczym elementem infrastruktury Ośrodka jest duży okrąg doświadczalny o długości 13,7 km. Składa się on z dwóch łuków o promieniu $1800 \mathrm{~m}$ oraz z dwóch odcinków prostych. Na okręgu znajduje się 6 mostów oraz 4 przejazdy w poziomie szyn. Maksymalna prędkość pociągów wynosi $200 \mathrm{~km} / \mathrm{h}$. Wewnątrz dużego okręgu znajduje się mały okrąg o długości 2,2 km, dostosowany do maksymalnej prędkości pociągów równej $60 \mathrm{~km} / \mathrm{h}$. Ponadto, na poligonie znajduje się tor $\mathrm{z}$ łukami odwrotnymi o małych promieniach (długość $1,3 \mathrm{~km}$ ), a także tor do badań zderzeniowych z górką rozbiegową o długości $0,3 \mathrm{~km}$. Całkowita długość torów na poligonie badawczym w Faurei wynosi $20,2 \mathrm{~km}$. Tory na poligonie są zelektryfikowane prądem przemiennym o napięciu $25 \mathrm{kV}$ i częstotliwości przemysłowej $50 \mathrm{~Hz}$. Na potrzeby badań dostępna jest hala o powierzchni $600 \mathrm{~m}^{2} \mathrm{z}$ kanałami rewizyjnymi, podnośnikami oraz suwnica.

Ośrodek Badań Kolejowych CTF Faurei zmodernizowano w latach 2004-2005 ze środków Unii Europejskiej w ramach projektu PHARE RO 0107.13 o łącznej wartości około 10 milionów EUR. Zakres modernizacji był następujący:

- odbudowa i budowa nowego podtorza,

- kompleksowa wymiana nawierzchni kolejowej na długości dużego okręgu z zabudową szyn typu 60E1,

- rozbiórka dwóch mostów i przebudowa pozostałych 6 obiektów,

- całkowita rekonstrukcja zasilania elektroenergetycznego,

- przebudowa urządzeń sterowania ruchem i sygnalizacji,

- zabudowa nowych urządzeń telekomunikacyjnych,

- remont instalacji elektrycznych i sanitarnych w budynkach.

Tor doświadczalny odgałęzia się od toru nr 2 linii nr 702 w km 165,195, pomiędzy Buzau i Faurei. Na okręgu możliwe jest wykonywanie różnego rodzaju badań pojazdów szynowych (rys. 11). W szczególności są to następujące badania:

- dynamika jazdy i bezpieczeństwo jazdy,

- komfort jazdy,

- układy hamulcowe,

- współpraca pantografu z siecią trakcyjną,

- hałasu od taboru,

- kompatybilność elektromagnetyczna.

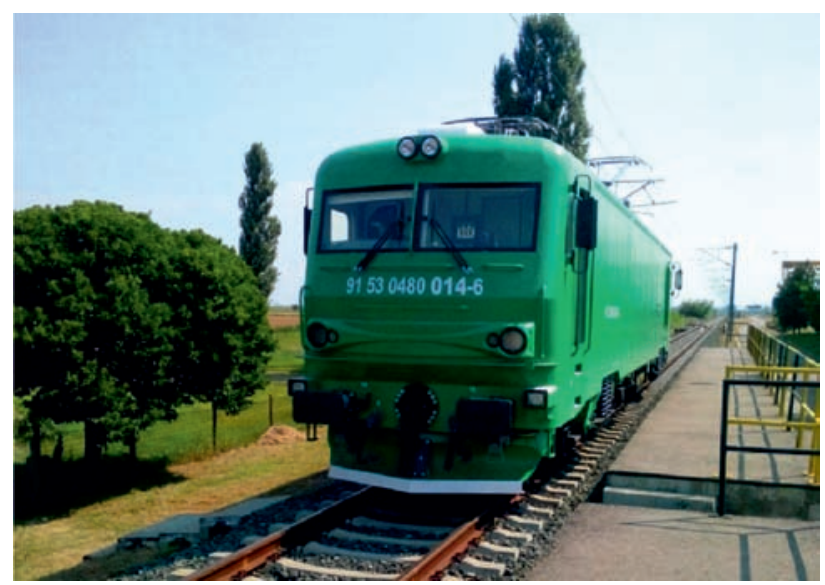

Rys. 11. Lokomotywa elektryczna produkcji SOFTRANS podczas badań na okręgu w Faurei [źródło: AFER]

\subsection{Okrąg doświadczalny Instytutu Kolejnictwa w Żmigrodzie (Polska)}

Ośrodek Eksploatacji Toru Doświadczalnego (OETD) jest usytuowany na terenie województwa dolnośląskiego, w odległości około $4 \mathrm{~km}$ na zachód od miasta Żmigród. Obiekt ma połączenie ze stacją kolejową Żmigród zlokalizowaną na linii kolejowej E59 Wrocław - Poznań.

Tor doświadczalny (krzywoliniowy o zamkniętym kształcie) o długości $7725 \mathrm{~m}$ jest zbudowany z 25 sekcji torowych o długości $300 \mathrm{~m}$ i sekcji rozjaz- 
dowej $225 \mathrm{~m}$. Nawierzchnia jest wyposażona w szyny UIC 60, częściowo na podkładach betonowych różnego typu oraz drewnianych - $\mathrm{z}$ drewna miękkiego i twardego. Przez odpowiednio dobrane rozmieszczenie poszczególnych rodzajów podkładów oraz różnego rodzaju przytwierdzeń, uzyskano odcinki toru różniące się pod względem konstrukcyjnym, jak i położeniem w płaszczyźnie poziomej. Ma to istotne znaczenie $\mathrm{w}$ prowadzeniu różnego rodzaju badań nawierzchniowych. Okrąg doświadczalny, oznaczony $\mathrm{nr} 2$, jest torem bezstykowym. Zbudowany jest $\mathrm{z}$ odcinków prostych o długościach 1313,9 m i 543,9 m oraz z czterech łuków poziomych o promieniach w zakresie od 600 do $900 \mathrm{~m}$ (tabl. 2).

Tablica 2 Charakterystyka łuków na okręgu doświadczalnym Instytutu Kolejnictwa

\begin{tabular}{|l|c|c|c|c|}
\hline Element & $\begin{array}{c}\text { Max. pręd- } \\
\text { kość } \boldsymbol{V}_{\max } \\
{[\mathbf{k m} / \mathbf{h}]}\end{array}$ & $\begin{array}{c}\text { Pro- } \\
\text { mień } \\
\boldsymbol{R}[\mathbf{m}]\end{array}$ & $\begin{array}{c}\text { Prze- } \\
\text { chyłka } \boldsymbol{h} \\
{[\mathbf{m m}]}\end{array}$ & \multicolumn{1}{|c|}{ Uwagi } \\
\hline Prosta & 160 & - & - & $\begin{array}{c}\text { Prędkość 160 km/h } \\
\text { niezbędna w bada- } \\
\text { niach hamulca }\end{array}$ \\
\hline Łuk 1 & 120 & 600 & 150 & - \\
\hline Łuk 2 & 120 & 700 & 115 & - \\
\hline Łuk 3 & 120 & 800 & 90 & - \\
\hline Łuk 4 & 140 & 900 & 100 & - \\
\hline
\end{tabular}

[Opracowanie własne].
Poza badaniami prowadzonymi na okręgu doświadczalnym, na terenie OETD są wykonywane badania przepychania taboru przez łuki odwrotne. Badania takie polegają na wymuszeniu określonych warunków dynamiki wzdłużnej składu pomiarowego w taki sposób, aby sprawdzić podatność badanego obiektu na możliwość wykolejenia przy działaniu dużych sił wzdłużnych. W tym celu wybudowano tor $\mathrm{nr} 4 \mathrm{z}$ łukami odwrotnymi o małych promieniach. Tor odgałęzia się od toru nr 2 rozjazdem $60-300$ - 1:9 w pobliżu $\mathrm{km}$ 0,00 i przebiega wzdłuż niego, w rejonie łuku o promieniu $600 \mathrm{~m}$ od jego strony wewnętrznej. Długość użytkowa toru wynosi $415 \mathrm{~m}$. Między odwrotnymi łukami jest wstawka prosta o długości $6 \mathrm{~m}$.

Specjalna konfiguracja okręgu doświadczalnego, a zwłaszcza istniejące łuki o promieniach $\mathrm{w}$ zakresie od $600 \mathrm{~m}$ do $900 \mathrm{~m}$, w połączeniu $\mathrm{z}$ ponad kilometrowym odcinkiem prostym, umożliwiają badania pojazdów pod względem ich dynamicznego zachowania. Prędkość $160 \mathrm{~km} / \mathrm{h}$, dopuszczalna na tym odcinku, umożliwia przeprowadzanie badań ruchowych układów hamulcowych $\mathrm{z}$ tą prędkością. Lokalizację odcinka przedstawiono na rysunku 12.

Na torze $\mathrm{nr}$ 2, w km 6,500 wydzielono odcinek, wokół którego zachowana jest neutralność akustyczna i charakteryzuje się podwyższonymi parametrami dynamicznymi oraz jakością układu geometrycznego toru. Służy on do prowadzenia badań hałasu zgodnie $\mathrm{z}$ wymaganiami Technicznych Specyfikacji Interoperacyjności. Na tym odcinku mierzony jest hałas od przejeżdżających pojazdów zarówno z ustaloną prędkością, jak i w trakcie rozruchu.

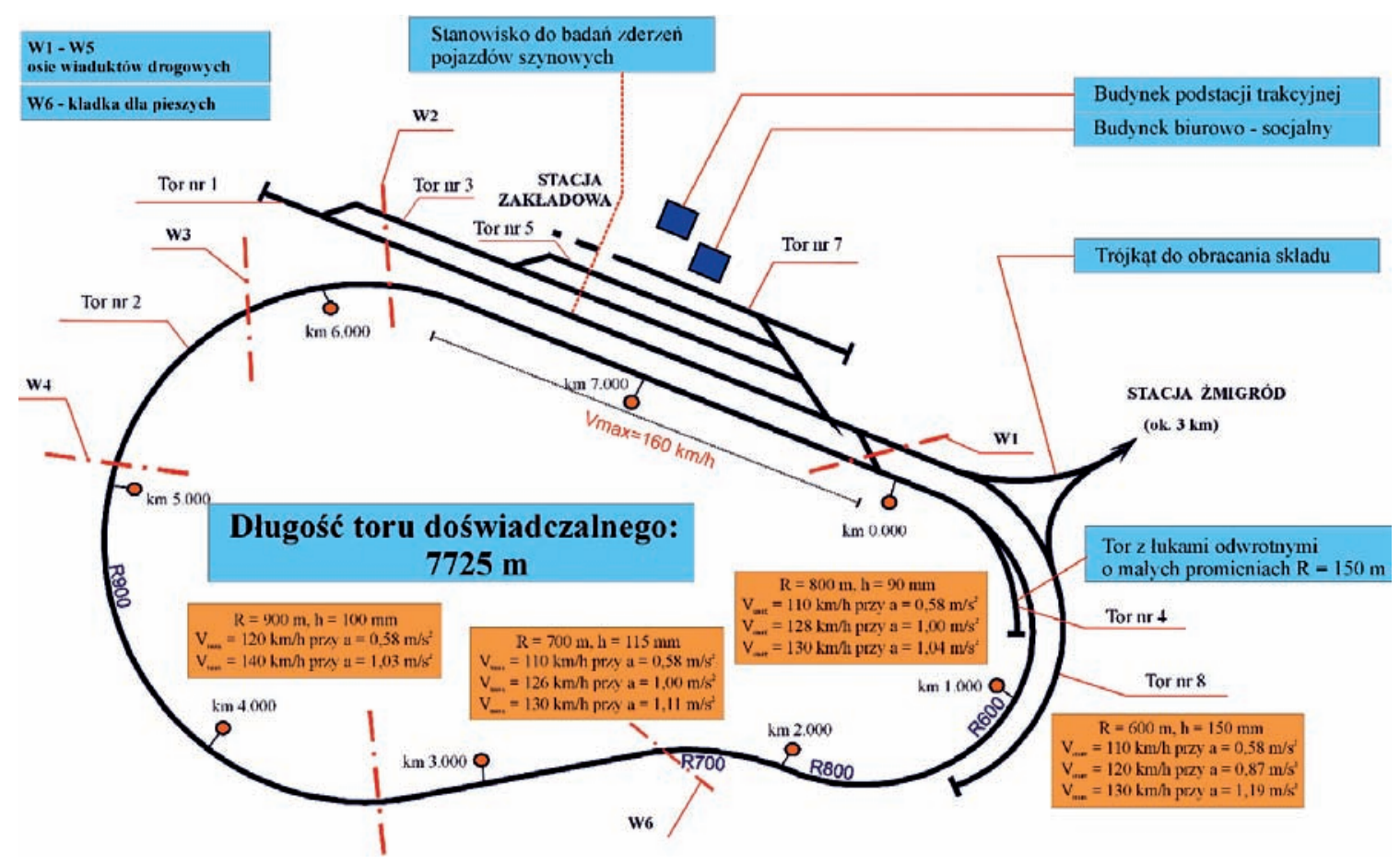

Rys. 12. Schemat układu torowego [opracował Tomasz Kędzierski] 
Okrąg doświadczalny w Żmigrodzie powstał na przełomie lat osiemdziesiątych i dziewięćdziesiątych $\mathrm{XX}$ wieku, jako pierwszy etap większego zamierzenia obejmującego również budowę dużego okręgu przeznaczonego do realizacji badań taboru przy dużych prędkościach jazdy. Istniejący tor, oddany do eksploatacji we wrześniu 1996 roku, był planowany przede wszystkim jako poligon do badań trwałościowych nawierzchni kolejowej, a także konstrukcji mostów. Jest pewnym paradoksem, że okrąg ten od wielu lat służy przede wszystkim do badań taboru. Jest na nim realizowana większość badań pojazdów wykonywanych przez Instytut Kolejnictwa na rzecz praktycznie wszystkich producentów taboru w Europie (w tym Alstom, Bombardier, Greenbrier, Newag, Pesa, Siemens, Stadler).

\subsection{Centrum Badawcze Wegberg-Wildenrath (Niemcy)}

Centrum badawcze Prüfcenter Wegberg-Wildenrath funkcjonuje od 1997 roku. Centrum dysponuje dwoma okręgami doświadczalnymi, przy czym na jednym $\mathrm{z}$ nich jest ułożony tor o szerokości normalnej (1435 mm), drugi okrąg zaś ma dwie szerokości toru: $1435 \mathrm{~mm}$ oraz $1000 \mathrm{~mm}$. Ponadto, na terenie ośrodka znajdują się 3 tory o przebiegu prostoliniowym.

Okrąg zewnętrzny T1 ma długość $6,082 \mathrm{~km}$ oraz promienie łuków $700 \mathrm{~m}$. Tor umożliwia wykonywanie jazd z prędkością maksymalną $130 \mathrm{~km} / \mathrm{h}$ na łukach i do $160 \mathrm{~km} / \mathrm{h}$ na odcinkach prostych. Zasadniczym przeznaczeniem zewnętrznego okręgu jest badanie pojazdów kolejowych (rys. 13).

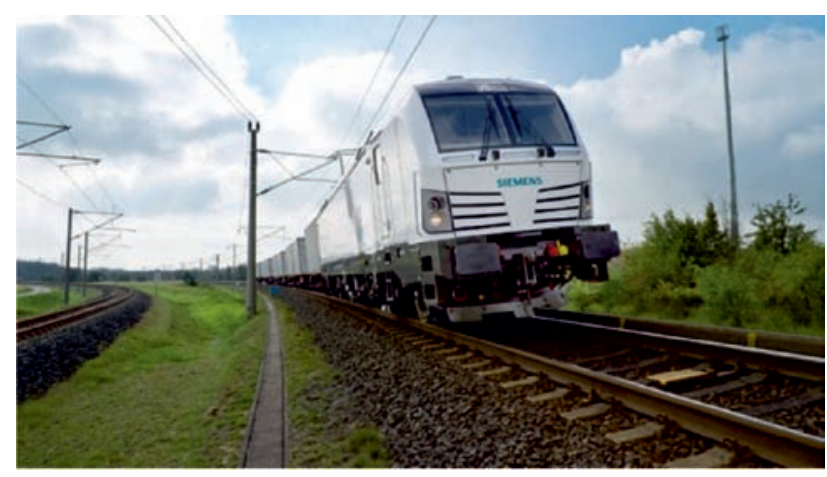

Rys. 13. Badania taboru na okręgu T1 w Wegberg-Wildenrath [źródło: Siemens Mobility]

Okrąg wewnętrzny T2 ma długość 2,485 km i jest dostosowany do jazdy z prędkością nie większą niż $80-100 \mathrm{~km} / \mathrm{h}$, w zależności od promienia łuku. Okrąg ten umożliwia badania pojazdów szynowych dostosowanych do szerokości toru $1435 \mathrm{~mm}$ oraz $1000 \mathrm{~mm}$, w tym także tramwajów. Tor doświadczalny T3 jest torem prostym, poziomym o długości
1,5 km, a jego głównym przeznaczeniem jest wykonywanie badań hamulcowych pojazdów o szerokości toru $1435 \mathrm{~mm}$ oraz $1000 \mathrm{~mm}$.

Wymienione tory są zelektryfikowane, z siecią napowietrzną dostosowaną do wszystkich możliwych systemów zasilania: $25 \mathrm{kV}$ prądu przemiennego o częstotliwości $50 \mathrm{~Hz}$ (a także $60 \mathrm{~Hz}$ ), $15 \mathrm{kV}$ o częstotliwości $16,7 \mathrm{~Hz}, 12 \mathrm{kV}$ o częstotliwości $25 \mathrm{~Hz}$ oraz do zasilania prądem stałym o napięciu od 400 do $4000 \mathrm{~V}$. Tory wyposażone są także $\mathrm{w}$ trzecią szynę, przy czym na okręgu zewnętrznym T1 jest to szyna typu brytyjskiego, a na okręgu wewnętrznym T2 oraz na torze do badań hamowania T3 - szyna typu berlińskiego. W centrum Wegberg-Wildenrath znajduje się łuk pomiarowy o bardzo małym promieniu, przeznaczony do badań pojazdów zgodnie z normą EN 14363 [25].

W 2009 roku w centrum badawczym WegbergWildenrath zabudowano 8 generatorów sygnałów, umożliwiających podjęcie badań aplikacji kolejowych wykorzystujących system nawigacji satelitarnej Galileo. Generatory sygnału zamontowane na masztach o wysokości $50 \mathrm{~m}$ zapewniają pokrycie obszaru o powierzchni 35 ha. Umożliwiło to testowanie takich aplikacji, jak śledzenie pociągów lub automatyzację rozrządzania [19].

Tory doświadczalne w Wegberg-Wildenrath są wykorzystywane przede wszystkim do badań pojazdów szynowych nowych typów oraz do integracji zespołów trakcyjnych produkcji Siemens, prowadzone są także badania innowacyjnych rozwiązań konstrukcyjnych. Przykładem były testy wózka nowej generacji, zabudowanego $\mathrm{w}$ spalinowym zespole trakcyjnym serii 612, które wykonano w 2004 roku na okręgach doświadczalnych w łukach o promieniach $300 \mathrm{~m}$ i $700 \mathrm{~m}$ [12].

\subsection{Tor doświadczalny Old Dalby (Wielka Brytania)}

Tor, zlokalizowany w hrabstwie Leicestershire, jest przede wszystkim przeznaczony do badań nowych typów pojazdów. Wykorzystuje on odcinek (wyłączonej z użytkowania pod koniec lat sześćdziesiątych XX w.) linii kolejowej pomiędzy Kettering i Nottingham. Tor, przygotowany na potrzeby ośrodka badawczego British Rail Research Division, był uruchomiony we wrześniu 1970 roku. Początkowo służył do badań realizowanych w ramach programu APT ( $A d-$ vanced Passenger Train). W szczególności prowadzono na nim badania konstrukcji sieci trakcyjnej oraz pantografów. Po prywatyzacji kolei w Wielkiej Brytanii stał się własnością agencji mienia kolejowego BRB i był udostępniany różnym podmiotom prywatnym. Od września 2013 roku tor jest własnością narodowego zarządcy infrastruktury (Network Rail). W strukturze Network Rail, tor funkcjonuje jako Melton Rail Innovation \& Development Centre (rys. 14). Siedziba 
centrum znajduje się w miejscowości Melton. Centrum dysponuje dwoma torami:

- Torem do jazd $\mathrm{z}$ dużymi prędkościami (do $201 \mathrm{~km} / \mathrm{h}$ ) pomiędzy Melton Junction i Edwaldton o długości 13 mil (około 20,9 km). Tor jest zelektryfikowany na długości $11 \mathrm{mil}(17,7 \mathrm{~km})$.

- Torem do jazd z prędkościami do 60 mil na godzinę $(96 \mathrm{~km} / \mathrm{h})$ o długości 4 mil $(6,4 \mathrm{~km})$.

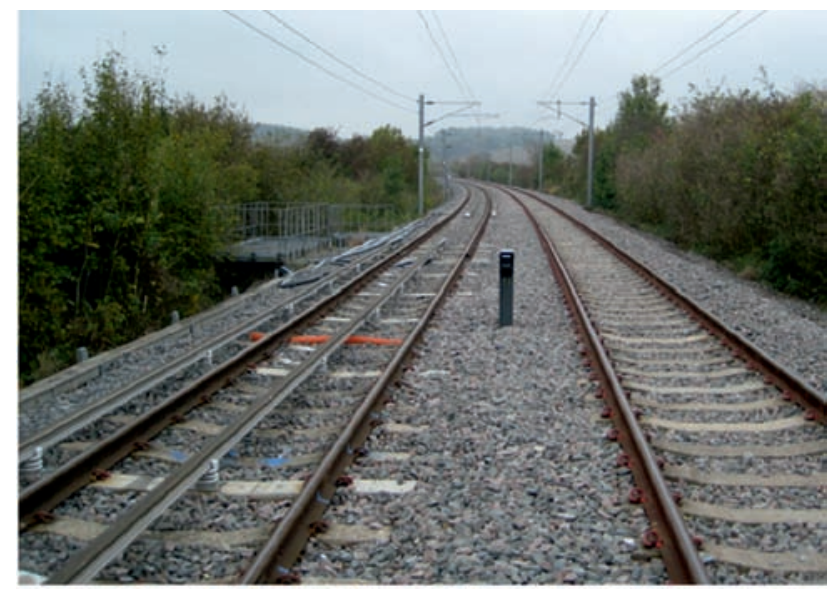

Rys. 14. Tory doświadczalne Melton Rail Innovation \& Development Centre - lewy tor jest przystosowany do badań taboru metra zasilanego z trzeciej szyny [źródło: www.railwaytechnical.com]

\subsection{Kolejowe Centrum Badawcze CEF (Francja)}

Kolejowe Centrum Badawcze CEF (Centre d'Essais Ferroviaires) utworzono we Francji w 1998 roku. W skład Centrum wchodzą dwa ośrodki: CEF1 w Petite-Forêt oraz CEF2 w Tronville-en-Barrois. Ośrodek CEF1 zlokalizowany w Petite-Forêt, w rejonie Vallencienes, dysponuje torami doświadczalnymi o różnym przeznaczeniu. Na torach wykonuje się badania taboru kolejowego, a także taboru do przewozów miejskich i podmiejskich (aglomeracyjnych): metra, tramwajów i pojazdów do systemów kolejowo-tramwajowych. Tory w ośrodku CEF1 mogą być zasilane $\mathrm{z}$ sieci trakcyjnej prądem przemiennym o napięciu $25 \mathrm{kV}$ i $15 \mathrm{kV}$, prądem stałym o napięciu $3 \mathrm{kV}, 1,5 \mathrm{kV}$ oraz $750 \mathrm{~V}$, a także z trzeciej szyny prądem stałym o napięciu $750 \mathrm{~V}$. Wśród torów doświadczalnych znajdują się dwa okręgi badawcze.

Okrąg badawczy VAE o długości 1,828 km, na zasadniczej części jest położony w łuku o promieniu $310 \mathrm{~m}$, jednak w torze znajduje się także łuk o promieniu $190 \mathrm{~m}$. Długość odcinka prostego wynosi $201 \mathrm{~m}$. Tor umożliwia przejazdy pojazdów szynowych przy wszystkich dostepnych systemach zasilania elektroenergetycznego. Maksymalna prędkość w torze VAE wynosi $90 \mathrm{~km} / \mathrm{h}$. Tor umożliwia prowadzenie badań urządzeń ERTMS (ETCS L2 oraz GSM-R).
Okrąg doświadczalny PASC1 jest przystosowany do badań pojazdów szynowych, a także pojazdów poruszających się na kołach ogumionych (w szczególności jest to tabor metra). Na torze przeprowadzane są również badania systemów autonomicznych (pojazdy bez maszynistów). Długość tego toru wynosi $1,798 \mathrm{~km}$ i znajduje się on wewnątrz okręgu VAE. Promienie łuków wynoszą $305 \mathrm{~m}$ oraz $185 \mathrm{~m}$, a długość odcinka prostego - $181 \mathrm{~m}$. Tor może być zasilany prądem stałym o napięciach $1,5 \mathrm{kV}$ oraz $750 \mathrm{~V}$ zarówno z sieci trakcyjnej, jak i z trzeciej szyny. Maksymalna prędkość w torze PASC1 wynosi $80 \mathrm{~km} / \mathrm{h}$.

Poza wymienionymi okręgami doświadczalnymi, w ośrodku CEF1 znajduje się także odcinek toru w kształcie litery C (układ otwarty, oznaczony jako VEV), o długości 2,750 km i prędkości maksymalnej pociagów równej $110 \mathrm{~km} / \mathrm{h}$. Tor jest przeznaczony do określania właściwości dynamicznych pojazdów. Promień łuku w tym torze wynosi $325 \mathrm{~m}$, maksymalne pochylenia $7,6 \%$ a maksymalna długość prostego odcinka $1400 \mathrm{~m}$. Ponadto, w ośrodku CEF1 znajduje się tor o długości $288 \mathrm{~m}$ do ważenia pojazdów, a także tor (stanowisko) do badań bezpieczeństwa przeciwko wykolejeniu (łuki o promieniu $150 \mathrm{~m}$ ) o długości $350 \mathrm{~m}$.

Ośrodek CEF2 jest zlokalizowany w departamencie Mozy (Meuse), w Trouville en Barrois, w pobliżu węzła kolejowego Bar-le-Duc. Ośrodek umożliwia prowadzenie badań taboru konwencjonalnego zarówno pasażerskiego, jak i towarowego. Tor badawczy, oznaczony jako VED, jest zlokalizowany wzdłuż eksploatowanej linii kolejowej a jego długość wynosi $12 \mathrm{~km}$. W torze znajdują się łuki o promieniach w zakresie od $750 \mathrm{~m}$ do $4500 \mathrm{~m}$, a także dwie proste o długości $1100 \mathrm{~m}$. Tor może być zasilany napięciem $25 \mathrm{kV}$ prądu przemiennego oraz $1,5 \mathrm{kV}$ prądu stałego. Prędkość maksymalna $-160 \mathrm{~km} / \mathrm{h}$.

\section{Planowane tory doświadczalne}

\subsection{Okrąg doświadczalny w Antequera (Hiszpania)}

W grudniu 2010 roku rząd Hiszpanii zaaprobował projekt budowy największego na świecie kolejowego okregu doświadczalnego. Ośrodek badawczy (Centro de Ensayos de Alta Tecnologia Ferroviaria) miał powstać na południu Hiszpanii w Andaluzji, w rejonie węzła kolejowego Antequera. Planowano budowę okręgu o długości $55 \mathrm{~km}$ (według innych źródeł $57,7 \mathrm{~km}$ ) i szerokości toru $1435 \mathrm{~mm}$, przeznaczonego do badań taboru przy bardzo dużych prędkościach jazdy (rzędu 450-500 km/h) [20]. Ponadto, przewidywano budowę mniejszego okręgu o długości $20 \mathrm{~km}$ i szerokości toru $1435 \mathrm{~mm}$ oraz $1668 \mathrm{~mm}$ (tor trój- 
szynowy) i prędkości maksymalnej $220 \mathrm{~km} / \mathrm{h}$. Całkowity koszt inwestycji szacowano na 344,45 milionów EUR i miał być wspólfinansowany przez Ministerstwo Nauki i Innowacji oraz Europejski Fundusz Rozwoju Regionalnego [20]. Na publiczne finansowanie tego rodzaju infrastruktury badawczej nie wyraziła zgody Komisja Europejska [3].

\subsection{Okrąg doświadczalny RFI w Bolonii (Włochy)}

W ostatnim okresie narodowy zarządca infrastruktury kolejowej we Włoszech, Rete Ferroviaria Italiana (RFI), podjął działania na rzecz zapewnienia możliwości wykonywania badań kolejowych w tym kraju. Największym przedsięwzięciem wydaje się przebudowa wyłączonej obecnie z użytkowania stacji rozrządowej San Donato w Bolonii [2]. Na jej terenie powstaje okrąg badawczy, składający się z jednotorowego odcinka o długości $5,759 \mathrm{~km}$ oraz odcinka dwutorowego o długości $2 \mathrm{~km}$ (rys. 15). Charakterystyka układu geometrycznego łuków znajdujących się na okręgu jest następująca (tabl. 3):

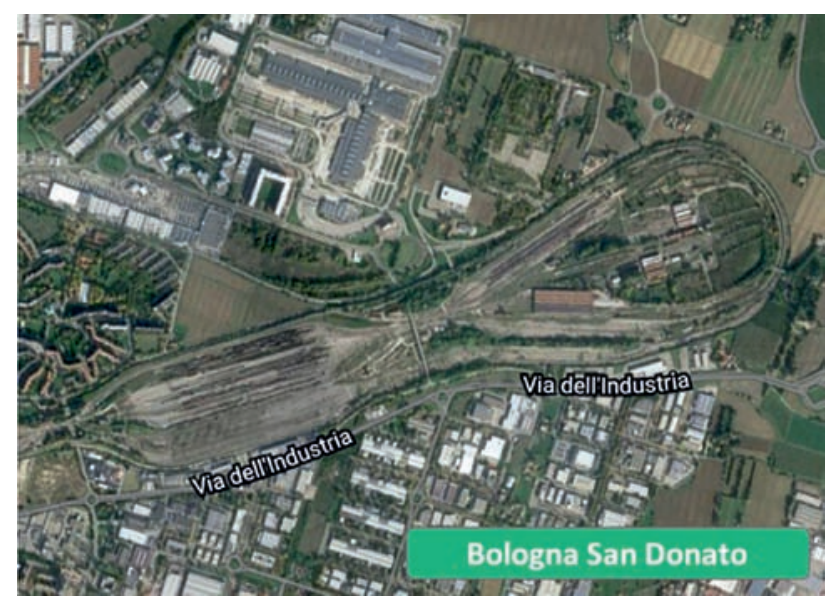

Rys. 15. Teren stacji rozrządowej San Donato [2]

Tablica 3

Charakterystyka łuków na budowanym okręgu doświadczalnym w Bolonii [2]

\begin{tabular}{|c|c|c|c|c|}
\hline Element & $\begin{array}{c}\text { Max. pręd- } \\
\text { kość } V_{\max } \\
{[\mathbf{k m} / \mathbf{h}]}\end{array}$ & $\begin{array}{l}\text { Pro- } \\
\text { mień } \\
R[\mathrm{~m}]\end{array}$ & $\begin{array}{c}\text { Prze- } \\
\text { chyłki } h \\
{[\mathrm{~mm}]}\end{array}$ & Uwagi \\
\hline Prosta & $120\left(140^{\star}\right)$ & - & - & \multirow{4}{*}{$\begin{array}{l}\text { Wartości prędkości } \\
\text { według kat. C } \\
\text { * zwiększone warto- } \\
\text { ści prędkości pod- } \\
\text { czas jazd w celu } \\
\text { określenia warun- } \\
\text { ków technicznych. }\end{array}$} \\
\hline Luk 1 & $110\left(125^{\star}\right)$ & 600 & 160 & \\
\hline Luk 2 & $95\left(105^{\star}\right)$ & 350 & 160 & \\
\hline Luk 3 & $75\left(85^{\star}\right)$ & 200 & 120 & \\
\hline
\end{tabular}

[Opracowanie własne].
Przewiduje się, że okrąg w Bolonii San Donato będzie wykorzystywany do:

- badań, weryfikacji oraz innych działań służących do tworzenia, testowania i certyfikacji elementów, a także systemów zarówno w odniesieniu do pojazdów szynowych, jak i infrastruktury,

- prac rozwojowych nad nowymi systemami i elementami infrastruktury, napędów elektrycznych, systemów sterowania $\mathrm{w}$ celu poprawy ich parametrów, zwiększenia niezawodności i podatności utrzymaniowej,

- kalibracji pokładowych systemów pomiarowych (na specjalnym stanowisku kalibracyjnym).

Prace nad budową infrastruktury badawczej okręgu $\mathrm{w}$ Bolonii podzielono na 4 etapy i zaplanowano na okres od października 2018 roku do grudnia 2019 roku. Pierwszy etap objął budowę jednotorowej pętli zasilanej w systemie $3 \mathrm{kV}$ prądu stałego i wyposażenie jej w różne, stosowane we Włoszech, systemy sterowania. W celu prowadzenia badań $\mathrm{z}$ wykorzystaniem systemu ERTMS, zaplanowano wyposażenie okręgu $\mathrm{w}$ RBC dopiero $\mathrm{w}$ ostatnim etapie, do końca 2019 roku.

Poza torem doświadczalnym w Bolonii, RFI dysponuje stanowiskami badawczymi we Florencji oraz laboratoriami w Rzymie:

- stanowiska Osmannoro we Florencji są przeznaczone do badań taboru, w tym hamulców, pantografów, wózków i są wyposażone w różne systemy zasilania trakcyjnego,

- laboratoria Portonaccio w Rzymie specjalizują się w badaniach konstrukcji, ocenie drgań i hałasu, a także w badaniach diagnostycznych na liniach kolejowych z wykorzystaniem pociągu pomiarowego.

\subsection{Tor doświadczalny w Corella (Hiszpania)}

Tor badawczy przeznaczony do różnego rodzaju badań taboru jest obecnie budowany w Hiszpanii. W dniu 17 lipca 2018 roku zarząd ADIF (Administrador de Infraestructuras Ferroviarias - zarządca infrastruktury kolejowej) podjął decyzję o udzieleniu firmie CAF (Construcciones y Auxiliar de Ferrocarriles) koncesji na budowę i eksploatację centrum badawczego w miejscowości Corella, w regionie Navarra. Do budowy toru zaplanowano wykorzystać odcinek długości $4 \mathrm{~km}$, będący częścią nieużywanej obecnie linii Soria - Castejón [1]. Koncesji udzielono na 20 lat, z możliwością przedłużenia na kolejne pięcioletnie okresy, nie dłużej jednak niż na 35 lat. Przewidziano możliwość wykorzystania dodatkowego terenu w celu rozbudowy toru, jeżeli zajdzie taka potrzeba, jednak koncesja może być cofnięta, gdyby niezbędne okazało się ponowne uruchomienie linii Soria - Castejón [1]. 


\subsection{Planowany tor doświadczalny w Walii}

W czerwcu 2018 roku ogłoszono plany budowy torów doświadczalnych $\mathrm{w}$ południowej Walii, przeznaczonych do badań pojazdów szynowych nowej generacji. Zakłada się zbudowanie dwóch torów w kształcie okręgu o długościach odpowiednio: $7,3 \mathrm{~km}$ oraz $3,1 \mathrm{~km}$, przeznaczonych do ruchu pociągów z prędkością do $160 \mathrm{~km} / \mathrm{h}$. Celem zbudowania ośrodka jest stworzenie warunków do rozwoju nowych technologii, w tym pojazdów o napędzie wodorowym oraz akumulatorowym, a także do badań infrastruktury, nowych systemów sterowania.

\subsection{Planowany tor doświadczalny w Indiach}

Na początku 2019 roku rząd Indii zaaprobował plan zbudowania toru doświadczalnego o długości 40 km w stanie Radżastan w północno-zachodniej części kraju. Zasadniczą przesłanką podjęcia takiej inwestycji jest potrzeba ograniczenia wykorzystywania istniejącej, bardzo obciążonej infrastruktury kolejowej do wykonywania badań pojazdów szynowych. Warto zwrócić uwagę, że koleje indyjskie (IR) były w 2016 roku krytykowane przez krajową władzę bezpieczeństwa (Commisioner of Railway Safety) za przeprowadzenie testów składu pociągu Talgo z prędkością do $180 \mathrm{~km} / \mathrm{h}$ na linii Delhi - Mumbai (Bombaj).

Proponowana lokalizacja przewiduje wykorzystanie odcinka dawnej linii Północno-Zachodniej pomiędzy Phulera i Jodhpur, który został zastąpiony przez linię o zmienionym przebiegu. Zakłada się, że w pierwszym etapie powstanie tor o długości $25 \mathrm{~km}$, $\mathrm{w}$ tym $20 \mathrm{~km}$ położonych na odcinkach prostych i $5 \mathrm{~km}$ w łukach o promieniach $1750 \mathrm{~m}$ oraz $875 \mathrm{~m}$, zgodnych $\mathrm{z}$ warunkami technicznymi obowiązującymi na kolejach indyjskich. Zakłada się, że na torze doświadczalnym będą wykonywane badania taboru, w tym badania spokojności jazdy, badania hamowania oraz badania sił na sprzęgach [16].

\section{Porównanie torów doświadczalnych}

Kolejowe tory doświadczalne zarówno obecnie eksploatowane, jak i planowane, powstawały w celu realizacji określonego rodzaju zadań, w tym badań elementów infrastruktury i badań taboru kolejowego, ale także integracji pojazdów wyprodukowanych w różnych zakładach oraz wykonywania prób uruchomieniowych. Różnorodne funkcje spełniane przez poszczególne tory doświadczalne sprawiają, że tory różnią się od siebie, niekiedy bardzo istot- nie (rys. 16). Ze względu na ukształtowanie, kolejowe tory doświadczalne można podzielić na dwie zasadnicze grupy:

- odcinki torów o określonej długości nie tworzące pętli,

- tory tworzące zamknięte pętle - okręgi doświadczalne.

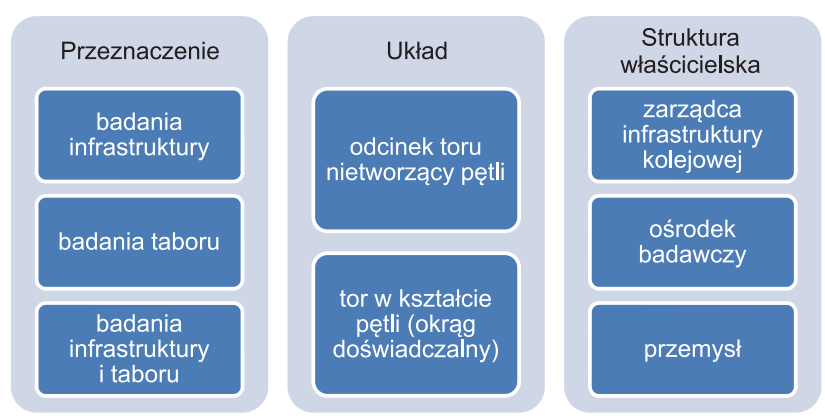

Rys. 16. Schemat opisujący funkcje torów [opracowanie własne]

Ze względu na przeznaczenie, możliwa jest następująca klasyfikacja torów doświadczalnych:

- tory do badań infrastruktury, w tym badań trwałościowych nawierzchni i obiektów,

- tory do badań taboru szynowego,

- tory wielofunkcyjne - do badań infrastruktury i taboru.

Szczególną grupą torów są okręgi doświadczalne. Zasadnicze charakterystyki eksploatowanych okręgów doświadczalnych przedstawiono w tablicy 4.

Wśród okręgów doświadczalnych można wyróżnić dwa zasadnicze ich rodzaje:

1. Okręgi o stałym promieniu łuku (o kształcie okręgu, rozumianego jako zbiór wszystkich punktów płaszczyzny odległych od ustalonego punktu, nazywanego środkiem, o zadaną odległość, nazywaną promieniem),

2. Pozostałe okręgi o kształcie zamkniętym, na których występują łuki o określonych promieniach, a także odcinki proste.

Do pierwszej grupy okręgów należą okręgi w Szczerbince oraz w Pekinie. Spośród drugiej grupy okręgów doświadczalnych najbardziej rozpowszechnione są te okręgi, które składają się z dwóch łuków o jednakowych promieniach o kącie zwrotu $180^{\circ}$ każdy, rozdzielonych dwoma odcinkami prostymi. Taki właśnie układ posiadają okręgi w Velimiu, w Faurei oraz w Wegberg-Wildenrath. Analizując promienie łuków na poszczególnych okręgach doświadczalnych, te okręgi można podzielić na trzy zasadnicze grupy, co pokazuje tablica 5 . 


\begin{tabular}{|c|c|c|c|c|c|c|}
\hline \multicolumn{7}{|c|}{ Porównanie charakterystyk okręgów doświadczalnych na Świecie } \\
\hline Ośrodek & Rok & $\begin{array}{l}\text { Długość } \\
\text { okręgu } \\
{[\mathrm{km}]}\end{array}$ & $\begin{array}{l}\text { Promień } \\
\text { luku [m] }\end{array}$ & $\begin{array}{c}\text { Prędkość } \\
\max .[\mathrm{km} / \mathbf{h}]\end{array}$ & Zasilanie & ERTMS \\
\hline Szczerbinka (Rosja) & 1932 & 6,000 & 956 & 140 & $25 \mathrm{kV}, 3 \mathrm{kV}$ & - \\
\hline Pekin (Chiny) & 1958 & 9,000 & 1433 & 120 & - & - \\
\hline Velim (Czechy) & 1963 & 13,276 & 1400 & $\begin{array}{c}210 \\
(230)\end{array}$ & $25 \mathrm{kV}, 15 \mathrm{kV}, 3 \mathrm{kV}, 1,5 \mathrm{kV}$ & ETCS L2 GSM-R \\
\hline- & 1971 & 3,951 & $300-800$ & $80-120$ & $25 \mathrm{kV}, 15 \mathrm{kV}, 3 \mathrm{kV}, 1,5 \mathrm{kV}$ & - \\
\hline Pueblo HTL (USA) & 1971 & 4,300 & $291-350$ & 64 & - & PTC \\
\hline Pueblo RTT (USA) & - & 21,700 & 1750 & 265 & $12,5 \mathrm{kV}, 25 \mathrm{kV}, 50 \mathrm{kV}$ & - \\
\hline Faurei (Rumunia) & 1978 & 13,7 & 1800 & 200 & $25 \mathrm{kV}$ & - \\
\hline- & - & 2,2 & $180-800$ & 60 & $25 \mathrm{kV}$ & - \\
\hline Żmigród (Polska) & 1996 & 7,725 & $600-900$ & $120-160$ & $3 \mathrm{kV}$ & ETCS L1 \\
\hline $\begin{array}{l}\text { Wegberg-Wildenrath } \\
\text { (Niemcy) T1 }\end{array}$ & 1997 & 6,082 & 700 & $130-160$ & $\begin{array}{l}25 \mathrm{kV}(50 \mathrm{~Hz}), 25 \mathrm{kV}(60 \mathrm{~Hz}), 15 \mathrm{kV} \\
(16,7 \mathrm{~Hz}), 12 \mathrm{kV}(25 \mathrm{~Hz}), 400-4000 \mathrm{~V}, \\
750 \mathrm{~V}\end{array}$ & ETCS L2GSM-R \\
\hline $\begin{array}{l}\text { Wegberg-Wildenrath } \\
\text { (Niemcy) T2 }\end{array}$ & - & 2,485 & 300 & $80-100$ & - & - \\
\hline Valenciennes (Francja) VEV & 2000 & 2,750 & - & $100-110$ & - & - \\
\hline VAE & - & 1,828 & $\begin{array}{l}310 \\
190\end{array}$ & 90 & $25 \mathrm{kV}, 15 \mathrm{kV}, 3 \mathrm{kV}, 1,5 \mathrm{kV}, 750 \mathrm{~V}$ & ETCS L2 \\
\hline PASC 1 & - & 1,798 & $\begin{array}{l}305 \\
185\end{array}$ & 80 & $1,5 \mathrm{kV}, 750 \mathrm{~V}$ & - \\
\hline
\end{tabular}

[Opracowanie własne].

Tablica 5 si $I=222 \mathrm{~mm}$ (wartość ta odpowiada przyspieszeniu Klasyfikacja kolejowych okręgów doświadczalnych

\begin{tabular}{|l|l|l|}
\hline \multicolumn{1}{|c|}{ Grupa } & \multicolumn{1}{|c|}{$\begin{array}{c}\text { Promienie } \\
\text { luków [m] }\end{array}$} & $\begin{array}{c}\text { Prędkość maksymalna } \\
{[\mathbf{k m} / \mathbf{h}]}\end{array}$ \\
\hline Okręgi duże & Powyżej 1000 & Powyżej 160 \\
\hline Okręgi średnie & $500-1000$ & $120-160$ \\
\hline Okręgi małe & $180-500$ & $60-100$ \\
\hline
\end{tabular}

[Opracowanie własne].

Wspólną cechą wszystkich okręgów doświadczalnych jest ścisłe dopasowanie dopuszczalnych prędkości do charakterystyki układu geometrycznego toru. $\mathrm{Z}$ tego względu maksymalne prędkości na poszczególnych okręgach są zazwyczaj zróżnicowane na ich długości. Prędkości te są w niektórych przypadkach określone przy założeniu relatywnie dużych wartości niedomiaru przechyłki, co wiąże się ze specyfiką wykonywania badań dynamicznych taboru kolejowego, przeprowadzanych zgodnie $\mathrm{z}$ normą $\mathrm{PN}$ EN 14363 [15]. Przykładowo, na dużym okręgu doświadczalnym w Velimiu znajdują się łuki o promieniu $R=1400 \mathrm{~m}$ i przechyłce $D=150 \mathrm{~mm}$. Przy prędkości maksymalnej dla taboru konwencjonalnego $V_{\max }=210 \mathrm{~km} / \mathrm{h}$, niedomiar przechyłki wynoniezrównoważonemu $a=1,45 \mathrm{~m} / \mathrm{s}^{2}$ ), to jest znacząco więcej niż wartość wyjątkowa dla tego przedziału prędkości, określona w normie EN 13803 (168 mm). Należy jednak podkreślić, że badania są praktycznie przeprowadzane przy mniejszych prędkościach, jak badania pokładowych urządzeń ETCS, które wykonuje się na torze w Velimiu przy prędkości do $200 \mathrm{~km} / \mathrm{h}$.

\section{Wnioski - potrzeby w zakresie infrastruktury badawczej w Europie}

W ramach inicjatywy Shift2Rail (S2R) rozwijane są nowe rozwiązania techniczne, mające przyczynić się do zwiększenia roli transportu szynowego we współczesnej gospodarce. Temu celowi służą liczne, międzynarodowe projekty badawcze współfinansowane ze środków Unii Europejskiej i przemysłu kolejowego. Efektem tych programów są tzw. demonstratory techniczne, które wymagają wszechstronnych badań. $\mathrm{Z}$ doświadczeń europejskiego przemysłu kolejowego wynika jednak, że jedną z głównych barier we wpro- 
wadzaniu na rynek nowych rozwiązań zarówno infrastrukturalnych, jak i taborowych, jest brak wystarczających możliwości ze strony kolejowych ośrodków zajmujących się takimi badaniami, a także dodatkowe koszty wynikające $\mathrm{z}$ rozmieszczenia geograficznego potencjału badawczego i z jego rozproszenia. W wyniku analizy jakościowej przeprowadzonej przez specjalną grupę S2R, przeanalizowano funkcjonowanie europejskich ośrodków, zajmujących się badaniami oraz innowacjami w kolejnictwie. Na potrzeby analizy ośrodki te zdefiniowano następująco:

- określona lokalizacja geograficzna / region lub dobrze zintegrowany klaster ośrodków w różnych lokalizacjach geograficznych,

- fizyczne (lub wirtualne) wykonywanie badań dla sektora kolejowego,

- prowadzenie badań przynajmniej przez jeden podmiot.

Wszystkie urządzenia, instalacje, pomieszczenia warsztatowe, budynki, tory, stanowiska badawcze, rozjazdy, urządzenia sterowania itp., nie stanowią osobnych ośrodków badawczych, ale są elementami (integralną częścią) ośrodka badawczego. W wymienionej analizie określono najważniejsze potrzeby dotyczące ośrodków badawczych służących badaniom oraz innowacjom na rzecz kolei europejskich:

- zwiększenie zdolności (capacity) do wykonywania badań - wykorzystanie stanowisk w istniejących ośrodkach jest duże, co powoduje konieczność oczekiwania lub zamówienia badań w innej, niekiedy odległej lokalizacji;

- zwiększenie możliwości (capabilities) badawczych istniejące ośrodki są często ściśle wyspecjalizowane, podczas gdy istnieje potrzeba holistycznego podejścia do badań i wykonywania ich w jednym miejscu;

- przyspieszenie wprowadzenia wyników programów badawczych oraz innowacyjnych na rynek przez testowanie i walidację prototypów;

- dostępność informacji i wiedzy o zdolnościach do wykonywania badań w poszczególnych ośrodkach i o ich możliwościach badawczych.

W celu zaspokojenia potrzeb, w inicjatywie Shift2Rail zaproponowano możliwe rozwiązania, $\mathrm{w}$ tym propozycję sieci ośrodków badawczych. Składają się na nią [23]:

- udostępnienie informacji o możliwościach ośrodków badawczych, prowadzące do optymalizacji ich wykorzystania;

- wykorzystanie nieeksploatowanych, mało obciążonych lub niedokończonych linii kolejowych;

- modernizacja istniejących ośrodków badawczych (również w celu przeprowadzania badań wirtualnych oraz symulacji);

- projektowanie i budowa nowych ośrodków badawczych ukierunkowanych na badania kolejowe.
W ramach prac Inicjatywy S2R, zaproponowano połączenie wymienionych rozwiązań w sześć scenariuszy:

- scenariusz 1: status quo + usieciowienie ośrodków, scenariusz 1+: scenariusz1 rozszerzony o włączenie niewykorzystanych lub słabo wykorzystanych linii kolejowych;

- scenariusz 2: rozbudowa istniejących ośrodków oraz ich usieciowienie, scenariusz 2+: scenariusz 2 rozszerzony o włączenie niewykorzystanych lub słabo wykorzystanych linii kolejowych;

- scenariusz 3: projektowanie i budowa nowych ośrodków i utworzenie sieci, scenariusz 3+: scenariusz 3 rozszerzony o włączenie niewykorzystanych lub słabo wykorzystanych linii kolejowych).

Jak widać, bardzo duże oczekiwania S2R są związane $z$ włączeniem niewykorzystywanych, słabo wykorzystywanych bądź niedokończonych linii kolejowych. Ponadto zakłada się, że do badań w warunkach eksploatacyjnych mogą być także użyte odcinki linii eksploatowanych, na których jest dostępna rezerwa przepustowości. Wszystkie rozwiązania wymagają odpowiedniego planowania i logistyki, jednak ich koszty powinny być akceptowalne. Należy przy tym wziąć pod uwagę, że w przypadku wykorzystania do badań linii obecnie nieużytkowanych (wyłączonych $\mathrm{z}$ eksploatacji), będzie konieczne ich zmodernizowanie i dostosowanie do nowych zadań, co będzie generowało koszty i wymagało czasu. Warto wskazać, że opisane wcześniej przypadki torów doświadczalnych powstających w Hiszpanii (Corella) i we Włoszech (San Donato) dobrze wpisują się w scenariusze zakładające możliwie jak największe wykorzystywanie do badań istniejącej infrastruktury kolejowej.

Idealne rozwiązanie Europejskiego Ośrodka Badań i Innowacji w Kolejnictwie (European Railway R\&I Testing Facility) zakłada następujące jego cechy [23]:

- dogodne położenie geograficzne i odpowiednie warunki klimatyczne,

- połączenie z Transeuropejską Siecią Transportową (TEN-T),

- część europejskiej sieci ośrodków badawczych,

- zdolność do wykonywania kompleksowych scenariuszy (przypadków) badań, przeprowadzanych w jednym miejscu (one-stop approach),

- możliwość wykonywania badań przez 24 godziny na dobę, 7 dni w tygodniu,

- zdolność do przeprowadzania badań ciężkich i długich pociągów (do $1500 \mathrm{~m}$ ),

- zdolność do przeprowadzania badań przy dużych prędkościach jazdy,

- dostępność rożnych systemów zasilania elektroenergetycznego,

- dostępność pojazdów testowych, pociągów i infrastruktury badawczej,

- dostępność urządzeń ERTMS wszystkich poziomów w celu wykonywania badań interoperacyj- 
ności, w tym ATO (automatyczne prowadzenie pociągu),

- stanowiska laboratoryjne oraz warsztaty,

- możliwość wykonywania symulacji numerycznych (testowania wirtualnego),

- kompleksowe usługi, urządzenia do przygotowania badań i ich oceny,

- dostępność wystarczającej liczby ekspertów, doświadczenie w wykonywaniu badań,

- zdolność do przeprowadzania oceny zgodności, akredytowane laboratorium.

Warto zwrócić uwagę, że okrąg doświadczalny Instytutu Kolejnictwa w Żmigrodzie, ma obecnie dużą część wymienionych cech. W najbliższych latach jest planowane zwiększenie jego możliwości badawczych. Obejmie ono modernizację zasilania elektroenergetycznego (zasilanie we wszystkich stosowanych w kolejnictwie europejskim systemach prądu przemiennego oraz stałego), zabudowę urządzeń systemu ETCS poziomu 2 oraz systemu GSM-R, jak również budowę hali dla pojazdów szynowych.

\section{Literatura}

1. CAF to develop Spanish test track, Railway Gazette International 2018, nr 9, s. 10.

2. Circuito di Test Bologna San Donato, Ricerca e Sviluppo, RFI, 2018, 25 października.

3. European Commission launches investigation into proposed $520 \mathrm{~km} / \mathrm{h}$ test track, Railway Gazette International, 24 marca 2015, WWW https:// www.railwaygazette.com/news/technology/single-view/view/european-commission-launchesinvestigation-into-proposed-520-kmh-test-track. html [dostęp 5.10.2020].

4. Fijałek M.: Tory doświadczalne, Problemy Kolejnictwa 1991, zeszyt 109, s. 66-85.

5. Grim J.: Železniční infrastruktura na zkušebním centru VUZ ve Velimi, Seminar Czech Raildays, 2007.

6. Li D., Bilow D.: Testing of slab track under heavy axle loads, Transportation Research Record 2008, Issue 2043, pp. 55-64.

7. Lisicyn A.L.: Eksperimentalnomy kolcu WNIIŻT - 70 let, Materiały konferencyjne „Eksperimentalnoje kolco WNIIŻT - 70", Szczerbinka 25-26 września 2002, s. 17-20.

8. Lisicyn A.L.: Uczionyje WNIIŻT-a. Intekst, Moskwa, 2003 (w języku rosyjskim).

9. Los D.: ŽZO Cerhenice: první zkušební dráha v Česku. Železničář 2017-12-07, WWW https:// zeleznicar.cd.cz/zeleznicar/skupina-cd/zzo-cerhenice--prvni-zkusebni-draha-v-cesku/-16569/ [dostęp 5.10.2020].
10. Massel A.: Dostosowanie linii konwencjonalnych w wybranych zarzadach kolejowych do prędkości jazdy równej lub większej od $200 \mathrm{~km} / \mathrm{h}$, Problemy Kolejnictwa, 2018, nr 178.

11. Massel A.: 25 lat kolei dużych prędkości we Francji, TTS Technika Transportu Szynowego, 2006, nr 10, s. 34-39.

12. Massel A. (red.): Rola okręgu doświadczalnego Instytutu Kolejnictwa $w$ badaniach taboru $i$ infrastruktury kolejowej, Wydawnictwo Naukowe Instytutu Kolejnictwa, Warszawa, 2021.

13. Oczykowski A.: Badania i rozwój przytwierdzenia sprężystego SB, Problemy Kolejnictwa 2010, nr 150, s. 121-156.

14. Orłow W. at.al.: Ispytania na opytnoj estakade eksperimentalnogo kolca - najboleje effektiwnyj sposob wyjawlienia osnownych eksploatacionnych kaczestw mostowych soorużenij, Materiały konferencyjne „Eksperimentalnoje kolco WNIIŻT - 70”, Szczerbinka 25-26 września, 2002, s. 204-206.

15. PN-EN 14363:2007: Kolejnictwo - Badania właściwości dynamicznych pojazdów szynowych przed dopuszczeniem do ruchu - Badanie właściwości biegowych i próby stacjonarne.

16. Rajasthan test track plan, Railway Gazette International, 2019, nr 3, p. 59.

17. Rakoczy A., Otter D.: Highlights of Railway Bridge Research and Testing by TTCI. Inżynieria Kolejowa - szanse i wyzwania, Politechnika Krakowska, Kraków 2018, p. 239-262.

18. Rakow W.A.: Lokomotiwy otecestvennych żeleznych dorog, Transport, Moskwa 1995 [w języku rosyjskim].

19. Siemens railway test site equipped for Galileo trials. Railway Gazette International. 10 sierpnia 2009, WWW https://www.railwaygazette.com/ news/siemens-railway-test-site-equipped-for-galileo-trials/34286.article [dostęp 5.10.2020].

20 . Spain to build $450 \mathrm{~km} / \mathrm{h}$ railway test circuit, Railway Gazette International, 20 grudnia 2010, WWW https://www.railwaygazette.com/news/ single-view/view/spain-to-build-450-kmh-railway-test-circuit.html [dostęp 5.10.2020].

21.Szablewski D., Kalay S., LoPresti J.: Development and Evaluation of High Performance Steels for Heavy Haul Operations, $9^{\text {th }}$ World Congress on Railway Research, Lille, 22-26 maj 2011.

22. Szinkariew B.: Skorostnoj ispytatielnyj poligon Biełorieczenskaja - Majkop - docziernoje priedprijatie eksperimentalnogo kolca WNIIŻT, Materiały konferencyjne „Eksperimentalnoje kolco WNIIŻT - 70", Szczerbinka 25-26 września 2002, pp. 230-232. ISBN 5-89277-038-9.

23. Test facilities for European rail research and innovation, Position Paper on capabilities, needs and scenarios, Shift2Rail, 2018. 
24. Velim test centre adapts to changing industry, IRJ, 19 listopada 2014, https://www.railjournal.com/ in_depth/velim-test-centre-adapts-to-changingindustry [dostęp 5.10.2020].

25. Weise T.: New measuring track curve in WegbergWildenrath test and validation centre, Eisenbahningenieur, 2009, nr 9.
26. Welsh Government reveals plans for rail testing facility www.railway-technology.com/news/walesrail-testing-facility/ [dostęp 5.10.2020].

27. WNIIŻT, Istoria i sowriemiennost, Moskwa, 2018.

28.https://www.cdvuz.cz/en/page/zkusebni-centrum-vuz-velim [dostęp 5.10.2020]. 